\title{
COMMENTS
}

\section{SWEEP AROUND YOUR OWN FRONT DOOR: EXAMINING THE ARGUMENT FOR LEGISLATIVE AFRICAN AMERICAN REPARATIONS}

\author{
TUNEEN E. CHISOLM ${ }^{\dagger}$
}

\begin{abstract}
As a world leader emphasizing the need for international relations grounded upon democracy and human rights, the United States has yet to face the dilemma of how to deal with its own past and its most egregious historical injustices, an obvious example being the legacy of slavery.
\end{abstract}

\section{INTRODUCTION}

The current state of race relations in America is charged with vigorous debates over the utility of a formal apology for slavery ${ }^{2}$ and the appropriate fate of affirmative action, ${ }^{3}$ as well as vivid reminders of past civil- and gov-

$\dagger$ Sc.B. 1984, Brown University; M.S. 1988, Lehigh University; J.D. Candidate 1999, University of Pennsylvania. I dedicate this Comment to my family-especially to the memory of my father and great-grandmother, Peter J. Chisolm and Emma Antley; to my mother, Doris Antley Chisolm, for planting the seeds of my consciousness; to my brother, Shahid, for watering those seeds; and to my daughter, Deyna M. Eman, for her love and support beyond expectation for such a little one. I thank Professors Lani Guinier and Stephen Perry for their insight. Finally, I thank my colleagues on the University of Pennsylvania Law Review for their editing assistance and the opportunity to be heard. All praises due to God.

${ }^{1}$ Elazar Barkan, Payback Time: Restitution and the Moral Economy of Nations, TIKKUN, Sept.-Oct. 1996, at 52, 58.

2 See Paul Magnusson, A New Ground Zero in the Race Debate?, BuS. WK., Sept. 22, 1997, at 10, 12 (reviewing STEPHAN THERNSTROM \& ABIGAIL THERNSTROM, AMERICA IN BLACK AND WHITE: ONE NATION INDIVISIBLE (1997)) (questioning whether a formal apology for slavery will have a significant impact on race relations); Jonathan Alter, The Long Shadow of Slavery, NEwSWEEK, Dec. 8, 1997, at 58, 62 (discussing the varying postures on a formal apology for slavery by the U.S. government); Nancy Mathis, Clinton Avoids Slavery Issue: President Asks Race Panel to Look at Education, Hous. CHRON., Oct. 1, 1997, at 4 (reporting President Clinton's refusal to discuss the topic of a formal apology for slavery at the first meeting of his Advisory Board on Race).

3 "We are witnessing a broad-based assault on affirmative action-in the courts, the legislatures, and the media." Susan Sturm \& Lani Guinier, The Future of Affirmative Action: Reclaiming the Innovative Ideal, 84 CAL. L. REV. 953, 953 \& nn.1-3 (1996) (footnotes omitted) (citing recent court cases, including Hopwood v. Texas, 78 F.3d 932 (5th Cir. 1996), state 
ernment-sanctioned transgressions against African Americans. ${ }^{4}$ The enslavement of Africans in America from 1619 to 1865 is one of the most callous, vexatious, near-genocidal violations of human rights in world history; ${ }^{5}$ that history is buried in the conscience of this Nation. ${ }^{6}$ The legacy of slavery in America is marked by the continued marginalization of African Americans within the firmly rooted, self-perpetuating economic caste system that is this Nation's foundation. ${ }^{\text {? }}$

President Clinton has a vision of America becoming "the world's first truly multiracial, multiethnic, multireligious democracy," so that we as a Nation will be "better positioned ... to lead the world toward peace and

and federal legislative efforts to repeal affirmative action, and negative press coverage of affirmative action that downplays continuing discrimination).

4 The media has played a key role in calling the Nation's attention to little-known or largely-forgotten incidents in the history of the African Holocaust through docudramas and movies. See, e.g., AMISTAD (DreamWorks SKG 1997) (portraying the uprising and subsequent trial of kidnapped Africans who revolted during their Middle Passage); GHOSTS of MISSISSIPPI (Castle Rock Entertainment 1996) (portraying the delay in bringing the assassin of civil rights leader, Medgar Evers, to justice); MISS EVERS' BOYS (Home Box Office Films 1996) (portraying the victimization of African American men who were subjected to syphilis and left untreated as part of what has become known as the Tuskegee experiment); ROSEWOOD (Peters Entertainment 1997) (portraying the destruction of a prosperous African American town in Florida and the massacre of its residents by a riotous white mob over the course of three days, without state action to control it). The Tuskegee experiment was a study of the effects of syphilis on untreated sufferers, conducted by the U.S. Public Health Service from 1932 to 1972. See JAMES H. JONES, BAD BLOOD: THE TUSKEGEE SYPHIIIS EXPERIMENT (new \& expanded ed. 1993). The subjects were 399 African American men in Macon, Alabama, who were unknowingly subjected to the debilitating progression of syphilis into the 1960s, despite the fact that medical treatment was available and a cure had been found by 1947. See id. (telling the story of the Tuskegee syphilis experiment).

5 See John Hope FrankLin \& AlFred A. MOSS, JR., From SLAVERy to FreEdom: A HISTORY OF AFRICAN AMERICANS 56-197 (7th ed. 1994) (discussing American slavery from its inception to its end).

${ }^{6}$ As one journalist puts it, "Slavery is such a gash in the national psyche that mainstream American culture rarely dares to touch it." Alter, supra note 2, at 60 ; see also supra note 4 (noting recent films dealing with the little-known and often-forgotten plight of African Americans).

${ }^{7}$ See Vincene Verdun, If the Shoe Fits Wear It: An Analysis of Reparations to African Americans, 67 TUL. L. REV. 597, 640 (1993) ("When slavery ended, it was replaced by a caste system designed to maintain the status quo of ... white supremacy. The caste system was supported by state and local laws, the courts, the Constitution as interpreted by the Supreme Court in Plessy v. Ferguson, and the American people." (footnotes omitted)). But cf. Plessy v. Ferguson, 163 U.S. 537, 559 (1896) (Harlan, J., dissenting) ("There is no caste here. Our constitution is color-blind, and neither knows nor tolerates classes among citizens."), overruled by Brown v. Board of Educ., 347 U.S. 483 (1954). See generally ERIC FONER, POLITICS AND IDEOLOGY IN THE AGE OF THE CIVIL WAR 10-11 (1980) (noting the centrality of slavery to the American experience, including the American Revolution and industrial expansion); infra text accompanying notes 147-51 (noting illustrations of the exclusion of African Americans). 
freedom and prosperity" in the twenty-first century. ${ }^{8}$ To that end, the President has commissioned the "President's Advisory Board on Race" to examine how we can end the racial divide that still pervades the Nation more than three decades after the end of overt, systemic discrimination and Jim Crow laws. ${ }^{9}$ The order provides that the board

shall advise the President on matters involving race and racial reconciliation, including ways in which the President can: (1) Promote a constructive national dialogue to confront and work through challenging issues that surround race; (2) Increase the Nation's understanding of our recent history of race relations and the course our Nation is charting on issues of race relations and racial diversity; (3) Bridge racial divides by encouraging leaders in communities throughout the Nation to develop and implement innovative approaches to calming racial tensions; [and] (4) Identify, develop, and implement solutions to problems in areas in which race has a substantial impact, such as education, economic opportunity, housing, health care, and the administration of justice. ${ }^{10}$

That agenda echoes the famous I Have A Dream speech in which Martin Luther King, Jr. painted his vision for a harmonious multiracial, multiethnic, and multireligious American democracy. ${ }^{11}$ That was three and onehalf decades ago, and still, America is far from reaching a true equal-access democracy in which every individual enjoys full citizenship ${ }^{12}$ and equal opportunity. ${ }^{13}$ "If we can finally achieve [that] multicultural balance, America

${ }^{8}$ President William J. Clinton, Remarks at the New England Presidential Luncheon, in Boston, Mass. (June 30, 1997), available in 1997 WL 10085085.

9 See Exec. Order No. 13,050, 3 C.F.R 207, 207-08 (1997) (establishing the President's Advisory Board on Race).

${ }_{10}$ Id. at 207 (emphasis added).

11 See Martin Luther King Jr., Keynote Address of the March on Washington, D.C. for Civil Rights (Aug. 28, 1963), in I HAVE A DREAM: WRITINGS AND SPEECHES THAT CHANGED THE WORLD 101, 105-06 (James Melvin Washington ed., 1992) ("[W]e will be able to transform the jangling discords of our nation into a beautiful symphony of brotherhood.... [A]ll of God's children-black men and white men, Jews and Gentiles, Catholics and Protestants-will be able to join hands ...."). The march marked the centennial of the Emancipation Proclamation.

12 The concept of full citizenship may be familiar, and yet unclear. See Talcott Parsons, Full Citizenship for the Negro American?: A Sociological Problem, 94 DAEDALUS 1009, 1009 (1965), reprinted in 1 RACE, LAW, AND AMERICAN HISTORY 1700-1990: THE AFRICAN AMERICAN EXPERIENCE 423, 423 (1992) ("As the British sociologist T.H. Marshall has shown with particular clarity, citizenship is a complicated matter which is by no means exhausted by the more literal meanings of the term "civil rights." (footnote omitted)). For clarification of the term "full citizenship" for purposes of this Comment, see infra Part II.C.

${ }^{13}$ See Luke Charles Harris \& Uma Narayan, Affirmative Action and the Myth of Preferential Treatment: A Transformative Critique of the Terms of the Affirmative Action Debate, 11 HARV. BLACKLETTER J. 1, 4 (1994) (focusing "on considerations of equality and full citizenship as they relate to the rights of Blacks and other marginalized Americans"). Harris and Narayan argue that women and people of color "continue to face institutional obstacles to equal consideration and equal treatment. These obstacles include not only continuing forms 
would unquestionably be perceived as the moral leader of a world characterized by intranational ethnic dissension and oppression.."14

In recent years, however, many have interpreted the very protections that were enacted to alleviate systemic racial discrimination against disadvantaged minority groups ${ }^{15}$ - namely, the Fourteenth Amendment and Title VII-in a way that threatens to eradicate progress. ${ }^{16}$ California's Proposition 209, ${ }^{17}$ which succeeded in amending the California Constitution, is spawning "copycat" legislation that ultimately may result in the demise of government affirmative action. ${ }^{18}$ Some affirmative-action opponents justify

of blatant racism and sexism, but, more importantly, a variety of subtle institutional practices that impede equal opportunity ...." Id. at 17-18. Studies reflecting the imbalance of the white and black experience bear this out. See, e.g., infra notes 171-73 and accompanying text (discussing evidence of racial discrimination in employment, housing, and loans).

${ }^{14}$ Rhonda V. Magee, The Master's Tools, from the Bottom Up: Responses to AfricanAmerican Reparations Theory in Mainstream and Outsider Remedies Discourse, 79 VA. L. REV. 863, 874 (1993).

${ }^{15}$ While the author acknowledges that American racial dynamics are not solely a matter of "black and white," the focus of this Comment is on African Americans. To that end, this Comment will discuss race relations in the context of the African American/white American experience.

${ }^{16}$ See, e.g., Taxman v. Board of Educ., 91 F.3d 1547, 1550 (3d Cir. 1996) (holding that the school board's affirmative-action plan violated Title VII because the plan, which was adopted to promote diversity by retaining minority teachers where potential candidates for layoffs were equally qualified, was not remedial in nature). It seems only logical that the strides gained through remedial actions-in this case the hiring of more minority teachersshould be preservable by allowing some consideration of diversity during downsizing, when all else is equal. Anything less would result in either: (1) pretextual hiring, where employers hire minorities to remedy past discrimination, but lay-off or fire for what appears to be a nondiscriminatory reason; or (2) cyclical hiring, where employers layoff minority teachers without consideration of their numbers, necessitating later affirmative efforts to "re-remedy" by hiring more minority teachers.

17 California's Proposition 209 provides, in part, that:

(a) The state shall not discriminate against, or grant preferential treatment to, any individual or group on the basis of race, sex, color, ethnicity, or national origin in the operation of public employment, public education, or public contracting.

....

(f) For the purposes of this section, "state" shall include, but not necessarily be limited to, the state itself, any city, county, city and county, public university system, including the University of California, community college district, school district, special district, or any other political subdivision or governmental instrumentality of or within the state.

(g) The remedies available for violations of this section shall be the same, regardless of the injured party's race, sex, color, ethnicity, or national origin, as are otherwise available for violations of then-existing California antidiscrimination law.

CAL. CONST. art. 1, $\S 31$. Ironically titled the 1995 Civil Rights Initiative, this state legislation effectively eliminates the use of affirmative-action programs by California state institutions.

${ }^{18}$ See Equal Opportunity Act of 1995, H.R. 2128, 104th Cong. (1995) (prohibiting "discrimination and preferential treatment on the basis of race, color, national origin, or sex with 
their position by suggesting that the elimination of all race-preferential policies in favor of a strict meritocracy reflects King's ideal. ${ }^{19}$ Against the backdrop of race-neutral policy reasoning, President Clinton's vision conjures up images of the utopian America that we have not been able to achieve-images of an America where people are judged by the "content of their character",20 and where we truly can all just get along. ${ }^{21}$ A discussion of whether colorblindness is a necessary step to achieve equality, or whether

respect to Federal employment, contracts and programs, and for other purposes"); Sturm \& Guinier, supra note 3, at 953 n.2 (noting the efforts of the Illinois, Georgia, and Pennsylvania state legislatures "to end race and gender preferences"). As government affirmative action declines, so too does private sector affirmative action. A recent disclosure of blatant discriminatory animus within the upper echelons of Texaco is illustrative:

This particular company's management structure has also been impervious to its previously stated diversity goals. One mid-level manager in Houston, when informed of a Black employee's discrimination complaint, replied, "I'd fire her Black a[**]." Informed that this was illegal, the manager sniffed, "I guess we treat niggers differently down here." That exchange was contained in an affidavit filed in federal court.

John William Templeton, Texaco Settlement Doesn't Settle the Underlying Power of Imbalance, WASH. AFRO-AM., Nov. 30, 1996, at A5.

19 See Equal Opportunity Act of 1995: Hearing on H.R. 2128 Before the Subcomm. on the Constitution of the House Comm. on the Judiciary, 104th Cong. 17 (1995) [hereinafter Hearing on H.R. 2128] (statement of Rep. Susan Molinari) ("Our country has long believed that people should be measured on their own merit, not because of their skin color or sex."); see also CERTAIN TRUMPET PROGRAM, TALKING BACK: FRAMING MEMO: THE AFFIRMATIVE ACTION DEBATE A4 (Sept. 1996) (identifying the I Have A Dream speech as a metaphor for the anti-affirmative-action position in favor of a color-blind society); CHRISTOPHER EDLEY, JR., NOT ALL BLACK AND WHITE: AFFIRMATIVE ACTION, RACE, AND AMERICAN VALUES 84 (1996) ("Critics of race-conscious measures often invoke Martin Luther King, Jr.'s 'content of their character' passage in urging that we hasten the realization of a color-blind society by insisting on color-blind practices now....").

Ironically, or perhaps not, those recalling this speech often overlook King's symbolic reference to America giving "the Negro people a bad check; a check which has come back marked "insufficient funds," which followed his likening of the Declaration of Independence to a promissory note. King, supra note 11, at 102 . Although the reference to a payment of debt may have been symbolic, Verdun argues that "King made the reference to the "bad check' in a historical context which carries the clear inference that the check was for historical wrongs." Verdun, supra note 7, at 604 n.21. King's frequent references to the American dream in other speeches were "directed mainly to the white public-the federal government, southern moderates, northern liberals, and religious communities-because he believed they had the material resources and the moral capacity to create a world based on the principles that they claimed to live by." JAMES H. CONE, MARTIN \& MALCOLM \& AMERICA: A DREAM OR A NIGHMMARE? 67 (1991). King concluded "that without economic justice, the right to a job or income, talk about 'life liberty, and the pursuit of happiness' was nothing but a figment of one's political imagination." Id. at 223.

${ }^{20} \mathrm{King}$, supra note 11, at 104.

21 Following the outbreak of the 1992 race riots in Los Angeles, Rodney King asked in striking simplicity: "Can't we get along? Can't we all just get along?" Matthew Dallek, $A f$ ter L.A., Hope Does Exist, S.F. EXAMINER, June 18, 1992, at A19, available in $1992 \mathrm{WL}$ 7582730. 
colorblindness is even desirable as an end objective, is beyond the scope of this Comment. However, "assum[ing] that our goal is a color-blind society, whatever that really means," act in a color-blind manner [will] hasten the day when people actually think in a color-blind way in their socially and economically significant dealings with others."23 The evidence suggests not. Despite some progress, "[e]conomic and social disadvantages remain powerfully linked with color, and this linkage exacts an enormous toll on the perception and reality of opportunity in America. Racial discrimination and race-based exclusion remain significant forces. 24

Therefore, I submit that at least one prerequisite to resolving the dilemma of race relations in America is reparations for African Americans. The issue addressed in this Comment is whether legislative reparations are a justifiable remedy for African Americans, particularly in light of the imminent dismantling of affirmative action with Proposition 209 and the decisions that have followed. ${ }^{25}$ Part I gives a brief overview of the quest for African American reparations since the end of slavery. Part II focuses on the continuing effects of slavery and systemic discrimination, and on the argument that continuing black and white inequities are rooted in such institutions. This Part discusses wealth as a measure of inequity to set the stage for determining damages and the appropriate compensation. Part III discusses why reparations are a prerequisite to an equitable society. In addition, Part III reflects on the "moral economy" incentive for granting reparations to African Americans. Part IV presents the rationale for a legislative remedy in the context of distributive justice. This section reviews the Civil Liberties Act as a precedent for race-based reparations, and discusses the arguments reconciling African American reparations and the Equal Protection Clause. Finally, Part V offers suggestions in answer to the who, what, and how of implementing an African American reparations scheme.

22 EDLEY, supra note 19 , at 82.

${ }^{23}$ Id. at 81-82.

24 Id. at 71 .

25 See Coalition for Econ. Equity v. Wilson, 122 F.3d 692 (9th Cir. 1997) (challenging, but failing to stop, the enactment of Article $1, \S 31$ of the California Constitution (Proposition 209) on the grounds that it denied equal protection and conflicted with federal civil rights statutes); see also CAL. CONST. art. 1, $\$ 31$ ("The state shall not discriminate against, or grant preferential treatment to, any individual or group on the basis of race, sex, color, ethnicity, or national origin in the operation of public employment, public education, or public contracting."); Hopwood v. Texas, 78 F. 3d 932 (5th Cir. 1996) (holding that the use of race as a factor in law school admissions in favor of increasing minority enrollment violates the 14th Amendment). 


\section{HISTORY OF THE QUEST}

Five major waves of political activism have promoted the idea of reparations for African Americans since the emancipation of slaves: (1) the Civil War Reconstruction Era, ${ }^{26}$ (2) the turn of the twentieth century, ${ }^{27}$ (3) the Garvey movement, ${ }^{28}(4)$ the Civil Rights movement, ${ }^{29}$ and (5) the resurgence of efforts following the Civil Liberties Act of $1988,{ }^{30}$ which, most re-

${ }^{26}$ See infra text accompanying notes 36-53 (discussing the implementation of the Confiscation Acts of 1861 and 1862 during the Civil War, the institution of the Freedmen's Bureau after the Civil War, and the Bureau's efforts to provide transitory assistance and some restitution to ex-slaves). For a detailed history, see generally GEORGE R. BENTLEY, A HISTORY OF THE FREEDMEN's BUREAU (1955), which discusses the origins of the Freedmen's Bureau after the Civil War, its impact on the lives of freed slaves, and its eventual demise.

27 "Efforts to get Congress to pass legislation [at the turn of the century] appropriating economic relief to freedmen were spearheaded by Walter $R$. Vaughan, a white businessman ... who also started the first ex-slave pension and bounty organization." Verdun, supra note 7, at 602. Meanwhile, "Mrs. Callie D. House and Reverend Isaiah H. Dickerson ... established the National Ex-Slave and Mutual Relief Bountys Pension Association in 1894 and actively promoted reparations to ex-slaves until the movement fizzled, when House and other members of the Association were indicted for mail fraud in 1916." Id. at 602-03.

${ }^{28}$ Marcus Garvey solicited funding to enable Africans to return to Africa for the formation of an independent nation. See generally THE PHILOSOPHY AND OPINIONS OF MARCUS GARVEY (Amy Jacques-Garvey ed., 1992) (discussing Garvey's perspective on the African Americans' problems and relocation to Africa as the solution). Garvey "told blacks that racial prejudice was so much a part of the civilization of whites that it was futile to appeal to their sense of justice and their high-sounding democratic principles." FRANKLIN \& MOSS, supra note 5, at 357. Garvey reportedly raised $\$ 10$ million between 1919 and 1921 , before he was imprisoned in 1925 for mail fraud. He was later pardoned by President Coolidge and deported back to Jamaica. See id. at 358-59 (recounting the rise of Garvey's Universal Negro Improvement Association and its eventual collapse because of Garvey's conviction and deportation).

29 See B. Kwaku Duren \& Neelam Sharma, The Case for Reparations, TURNING POINT, Feb.-Mar.-Apr. 1998, at 36, 37 (writing that in the 1960s, the Black Panthers demanded restitution); see also id. at 37 (noting activist Queen Mother Audley Moore's appeal to the United Nations for reparations); Verdun, supra note 7, at $605 \mathrm{n} .23$ (noting the lobbying efforts for reparations by Queen Mother Audley Moore). Calls for reparations during this time-particularly the Black Manifesto and the efforts of the Panthers Movement-were perceived as radical and, unfortunately, led to further marginalization of the idea. See, e.g., Magee, supra note 14, at 883 (noting the relegation of reparations proposals to "a marginal position as a 'radical' alternative among remedial options" and stating that James Forman's 1969 "'Black Manifesto' demand for reparations from white churches stunned and alienated the white religious world of the post-Martin Luther King era"); see generally BLACK MANIFESTO: RELIGION, RACISM, AND REPARATIONS (Robert S. Lecky \& H. Elliott Wright eds., 1969) (collecting articles by authorities on the Black Manifesto and reparations). Affirmative action was the compromise to the more organized pressures of the Civil Rights Movement. See Magee, supra note 14, at 884 ("Soon after Forman's historic speech, affirmative action began its rocky road of partial acceptance and implementation.").

${ }^{30}$ See infra Part IV.C (discussing the Civil Liberties Act, which provided for reparations to Japanese American internment victims and relocated Aleuts from World War II). The passage of the Civil Liberties Act in 1988 spawned a number of reparations initiatives for African 
cently, has been fueled by the trend toward an official dismantling of affirmative-action policies. The redress sought has included claims for back pay of slave wages; land acquisition and educational benefits, ${ }^{31}$ monetary compensation for abuse, indignities suffered, forced indoctrination into a foreign culture, and/or destruction of the family unit; ${ }^{32}$ relocation to Africa or designated lands; ${ }^{33}$ relief from income tax obligations; ${ }^{34}$ and forty acres and a mule, or the equivalent value. ${ }^{35}$ For purposes of this Comment, the focus is narrowed to only that compensation necessary to enable slave descendants to function in an America with race-neutral policies. Consequently, exodus and other separatist options are not considered.

Americans: the formation of the National Coalition of Blacks for Reparations in America ("N'COBRA") in 1989 as an umbrella organization for dozens of locally based organizations across the Nation; an unsuccessful 1993 class action suit against the United States government for tax immunity; a 1994 petition for reparations filed with the United Nations Subcommission on Human Rights Violations by the Lost and Found Nation of Islam, on behalf of African Americans, against the United States; and the birth of the reparations bill which is now known as H.R. 40. See Duren \& Sharma, supra note 29, at 37 (discussing each of these initiatives).

${ }^{31}$ See Eric Schnapper, Affirmative Action and the Legislative History of the Fourteenth Amendment, 71 VA. L. REV. 753 (1985) (detailing the development of the Freedmen's Bureau from 1861 to 1870); see also infra text accompanying notes $41-53$ (discussing the Freedmen's Bureau Acts).

${ }^{32}$ See Cato v. United States, 70 F.3d 1103, 1106 (9th Cir. 1995) (seeking "compensation of $\$ 100,000,000$ for forced, ancestral indoctrination into a foreign society; kidnapping of ancestors from Africa; forced labor; breakup of families; removal of traditional values; deprivations of freedom; and imposition of oppression, intimidation, miseducation and lack of information about various aspects of their indigenous character").

${ }^{33}$ See supra note 28 (discussing the exodus movement initiated by Marcus Garvey).

${ }^{34}$ See Calvin J. Allen, The Continuing Quest of African Americans to Obtain Reparation for Slavery, NAT'L B. AsS'N MAG., June 9, 1995, at 33, 33 (discussing numerous historical attempts by African Americans to obtain reparations for slavery); Peter M. Berkery, Jr., IRS Again Denies Reparation Claims, ACCT. TODAY, Aug. 12, 1996, available in 1996 WL 8970172 (discussing the receipt and denial of thousands of reparation claims by the IRS); IRS Receives Thousands of Claims for Slavery Reparation, J. ACCT., Oct. 1996, at 34, 34 (reporting on the thousands of tax claims for reparations that have been received and rejected by the IRS); cf. I.R.C. $\$ 6702$ (1994) (imposing a penalty for "frivolous" claims, which has been interpreted to include claims for reparations).

35 See Allen, supra note 34, at 33 (reporting one estimate that the 40 acres and a mule due to four million slaves in 1886 was valued at $\$ 300-\$ 500$ million or $\$ 43,209$ per African American household in 1995); IRS Receives Thousands of Claims for Slavery Reparation, supra note 34, at 34 (noting that, as of 1996, economists estimated the value of 40 acres and a mule at $\$ 40,000$ ). Anyone who has seen a Spike Lee production is at least vaguely familiar with this phrase that has become a shorthand for the African American claim to slave reparations. Spike Lee is a film producer who has incorporated his production company under the name "Forty Acres and a Mule Filmworks." See Nina Darnton, Film Notes: Film's $300 \mathrm{Ex}$ tras Belong to a Tribe, S.F. CHRON., Nov. 5, 1986, at 50. The term originates from the vetoed Freedmen's Bureau bill which initially proposed to distribute land to freed slaves. See infra text accompanying notes 46-52 (discussing the modification of the 1866 Freedmen's Bureau bill to exclude the provisional 40 acres to freed slaves so that the bill could override President Johnson's veto). 
Early reparations measures were legislative remedies which Congress promoted not only to aid the transition of freed Africans from slavery to freedom, but also to gain leverage during the Civil War through confiscation of land from rebels. ${ }^{36}$ According to Foner, the "Confiscation Act, of August 1861 , was directed only against property used in aid of the rebellion."37 The 1862 Confiscation Act authorized the taking of all rebel property, amassing thousands of acres of land; however, "President Lincoln, who strongly opposed widespread confiscation, forced Congress to ... limit[] the seizure of land to the lifetime of the owner. ${ }^{38}$ The Lincoln administration did little to enforce the 1862 Act, which was eventually repealed to make way for a measure authorizing permanent seizure. ${ }^{39}$ Nevertheless, freedmen were permitted to settle on thousands of acres of abandoned land in South Carolina and Georgia pursuant to General Sherman's field order. ${ }^{40}$

The Freedmen's Bureau Act of $1865^{41}$ created the Bureau of Freedmen's Affairs to provide special assistance to refugees and persons of African descent. The 1865 Act, effective for one year, authorized the lease and sale of confiscated land to refugees and Africans and was broad enough to enable the Bureau to supply basic necessities and medical assistance. ${ }^{42}$ The 1866 Freedmen's Bureau bill, ${ }^{43}$ in turn, proposed to extend the 1865 Act indefinitely, to authorize Congress's appropriation of funds to purchase school buildings for refugees and freedmen, and to empower the President to "reserve up to three million acres of 'good' public land," for lease and sale "to freedmen and refugees in parcels not exceeding forty acres." ${ }^{, 44}$ The 1866 bill passed in both the House and the Senate, but President Johnson unexpectedly vetoed the bill, and it failed to garner enough votes to override the veto. ${ }^{45}$ The bill was modified to exclude the land reservation-no forty

36 See ERIC FONER, POLITICS AND IDEOLOGY IN THE AGE OF THE CIVIL WAR 131 (1980) (" $[A] s$ the war progressed, increasing numbers of Republicans were converted to the view that the confiscation of rebel property would be a legitimate war measure.").

37 Id.

38 Id.

39 See id. at 132 (noting that no measure effecting a permanent seizure was ever enacted).

40 See id. (referring to General Sherman's order settling freedmen on abandoned land in South Carolina and Georgia then held by the government).

41 Act of Mar. 3, 1865, ch. 90, 13 Stat. 507.

42 See Schnapper, supra note 31, at 760-61 (recounting the three substantive provisions of the 1865 Freedmen's Bureau Act which authorized the confiscation and sale of abandoned land to freedmen and gave the Bureau "the control of all subjects relating to refugees and freedmen'").

${ }^{43}$ S. 60, 39th Cong. (1866).

44 Schnapper, supra note 31, at 762.

45 See id. at 769-71 (discussing President Johnson's unexpected veto of the 1866 Freedmen's Bureau Bill and the unexpected switch by several supporters of the bill after Johnson's lengthy veto message, such that the veto could not be overridden). 
acres - and to extend the Bureau Act for only two years; however, the new bill "provided special aid and protection" for African Americans that was "substantially more explicit than the vetoed bill or the 1865 Freedmen's Bureau Act."

First, the modified 1866 Act authorized the Bureau to assist freed African Americans as necessary to ensure that their freedom was "available to them and beneficial to the Republic," $" 47$ but limited the authorized assistance to white refugees to "that assistance necessary to make them selfsupporting." freed African Americans, whereas the vetoed bill had authorized "construction of schools 'for refugees and freedmen dependent on the Government for support." ${ }^{\prime 49}$ Third, the modified bill provided protections to free African Americans who were already occupying certain abandoned land pursuant to General Sherman's field order. ${ }^{50}$ Fourth, the modified bill prohibited only discrimination on the basis of race or color or previous condition of slavery, instead of also protecting refugees from discriminatory administration of civil and criminal law. ${ }^{51}$ Again Johnson vetoed the bill, but Congress voted to enact the 1866 Act nonetheless. ${ }^{52}$ The Act went into effect in 1868, and for two years, the Freedmen's Bureau enacted legislation for the education of freed African Americans. ${ }^{53}$ In 1870, however, a bill proposing indefinite continuation of education benefits passed in the House but died in the Senate, ending the Freedmen's Bureau activity. ${ }^{54}$

Since the Freedmen's Bureau Acts, there has been no consistent measure of reparations for African Americans. ${ }^{55}$ In 1989 and in every session of

${ }^{46} \mathrm{Id}$. at 773 (discussing H.R. 613, 39th Cong. (1866) (later enacted as Act of July 16, 1866 , ch. 200, 14 Stat. 173)).

47 Id. at 772 (quoting Act of July 16, 1866, ch. 200, 14 stat. 173, 174).

48 Id.

49 Id. (quoting S. 60, 39th Cong., $\$ 1$ (1866)).

${ }^{50}$ See id. at 773 n.106 (describing the bill's specific reference to General Sherman's order).

51 See id. at 773 (describing the modified bill's lessened protection for white refugees).

52 See id. at 774-75 (stating that President Johnson's opposition was based in a distaste for "special treatment" for African Americans).

${ }^{53}$ See id. at 780-81 ("In most years more than two-thirds of all funds expended by the Bureau were used for the education of freedmen.").

54 See id. at 783 (discussing the demise of the Freedmen's Bureau).

55 Although some would argue that affirmative action is a form of reparations, affirmative action has not impacted significantly the African American masses, particularly those of lower socioeconomic status. See CORNELl WEST, RACE MATTERS 63 (1993) ("Like earlier de facto affirmative action measures in the American past[,] ... recent efforts to broaden access to America's prosperity.... always benefit middle-class Americans disproportionately."). 
Congress since 1993, the African American Reparations Commissions Act ("H.R. 40") has been introduced, calling for the establishment of a Commission to Study Reparations Proposals for African Americans. ${ }^{56}$ To date, the bill has not gone past the Committee on the Judiciary.

\section{The Legacy OF SLAVERY: DeFINING THE HARM}

Disparities in wealth between blacks and whites are not the product of haphazard events, inborn traits, isolated incidents or solely contemporary individual accomplishments. Rather, wealth inequality has been structured over many generations through the same systemic barriers that have hampered blacks throughout their history in American society: slavery, Jim Crow, so-called de jure discrimination, and institutionalized racism. ${ }^{57}$

Simply put, reparations for African Americans is a touchy subject. ${ }^{58}$ The inequalities between blacks and whites in America often manifest themselves, and are therefore expressed, in terms that do not clearly relate back to slavery and the ensuing discrimination. For example, African Americans represent approximately $12 \%$ of the population, but account for $45 \%$ of prisoners nationwide; ${ }^{59}$ African Americans are 6.8 times more likely

Critics of any type of amends [including reparations] for ... . African Americans say blacks have already received retribution through the Freedmen's Bureau and more recently through affirmative action. Proponents counter that neither adequately addressed the legacies of slavery, particularly since they were both cut off before their time.

Duren \& Sharma, supra note 29, at 37.

56 See Commission to Study Reparation Proposals for African Americans Act, H.R. 40, 105th Cong., $\$ 2$ (b) (1997) (sponsored by Rep. John Conyers) (proposing to establish a commission to examine the institution of slavery, subsequent de jure and de facto racial and economic discrimination against freed slaves and their descendants, and the impact of these experiences on living African Americans, and to recommend "appropriate remedies"); H.R. 891, 104th Cong. (1995) (same); H.R. 40, 103rd Cong. (1993) (same); H.R. 3745, 101st Cong. (1989) (same). For a summary of the proposed legislation, see infra text accompanying note 259, discussing the key provisions of H.R. 40.

57 MELVIN L. Oliver \& ThOMAS M. SHaPIRO, Black Wealth/White WEALTH: A NEW PERSPECTIVE ON RACIAL INEQUALITY 12-13 (1995).

58 See Alter, supra note 2, at 63 ("Americans whose forebears didn't own slaves (even in the antebellum South, 95 percent did not) or arrived here after slavery ended are understandably resistant to the idea that they bear direct responsibility for slavery because of their skin color.").

59 See ANDrew HaCker, Two Nations: Black and White, SeParate, Hostile, UNEQUAL 246 (1995) (presenting statistics for African American prisoners versus the national population and selected state populations); see also Charles J. Ogletree, Blind Justice?: Race, the Constitution, and the Justice System, in AFRICAN AMERICANS AND THE LIVING CONSTITUTION 235, 235-59 (John Hope Franklin \& Genna Rae McNeil eds., 1995) (discussing racial disparities in sentencing, prosecutorial discretion, exercise of police discretion, jury deliberations, and the application of statutes). 
than whites to be homicide victims; ${ }^{60}$ African American families are 4.3 times more likely to live below the poverty level than whites; ${ }^{61}$ African Americans are only $65 \%$ as likely as whites to own their own home; ${ }^{62}$ and the teenage pregnancy ratesof African Americans is twice that for whites. ${ }^{63}$ Moreover, the unemployment rate of African Americans is more than twice than that of whites; ${ }^{64}$ whites are at least two times more likely to have completed four or more years of college than African Americans; ${ }^{65}$ and while the median income for whites increased by $11 \%$ from 1970 to 1992 , that of African Americans decreased by $1 \% .{ }^{66}$

The connection between historical race bias and these statistics-particularly those for teenage pregnancy, imprisonment, and homicide-is not readily apparent. To assume that the statistics reflecting black and white inequities have no relation to past patterns of discrimination is to accept an argument that these statistics reflect the true inherent abilities or disabilities of African Americans. As the ensuing discussion will show, however, and as other studies have shown, this is not the case. ${ }^{67}$ The result of this appar-

${ }^{60}$ See HACKER, supra note 59, at 241 (figure rounded). Death rates were higher for African Americans as a compared to whites for 21 of the 24 cause-of-death categories presented, including homicide, various diseases, pregnancy and childbirth, infant death, and druginduced causes. See $i d$. The three causes of death that were not higher were motor vehicle accidents occurring at $98 \%$ of the white rate, pulmonary disease at $83 \%$, and suicide at $57 \%$. See id.

${ }^{61}$ See id. at 106 (figure rounded).

62 See OLIVER \& SHAPIRO, supra note 57, at 109.

63 See HACKER, supra note 59 , at 82 (showing an under-18 pregnancy rate of $40.7 \%$ for blacks and $20.5 \%$ for whites).

${ }^{64}$ See HACKER, supra note 59, at 109 (showing that African American unemployment was 2.15 times that of whites for 1993 and that the averaged comparative rates for the $1960 \mathrm{~s}$, 1970 s, and 1980 s were $2.09,2.02$, and 2.37, respectively); OLIVER \& SHAPIRO, supra note 57, at 24.

65 See HACKER, supra note 59, at 244 (showing that the number of whites with four or more years of college was $211 \%$ greater than that of African Americans in 1993, 246\% greater in 1960 , and $400 \%$ greater in 1940 ).

${ }^{66}$ See id. at 104 (showing income in 1992 dollars changing from $\$ 36,494$ in 1970 to $\$ 40,421$ in 1992 for white families, and from $\$ 21,330$ in 1970 to $\$ 21,161$ in 1992 for black families).

${ }^{67}$ Cf. Ronald J. Fiscus, The CONSTTtutional Logic of AfFIRMATIVe ACTION 19-20 (Stephen L. Wasby ed., 1992) (arguing that "[i]f there are no race-correlated differences in intellectual ability at birth, and no differences in character," and no racism to impact opportunity, attitudes and values, then the pool of best qualified applicants for a graduate school would proportionally reflect the racial makeup of the population). Although Fiscus's argument is idealistic, it does have evidentiary indications of merit.

The correlation between family income and SAT [scores] is nearly four times larger than the incremental improvement in prediction offered by the SAT used in conjunction with high school grades.... Within each racial and ethnic group, SAT scores increase with income. 
ent disconnection is often a reflexive denial of the relationship between slavery and the Jim Crow era to any racism that exists today. ${ }^{68}$ The need for a more concrete way of assessing the injury to African Americans is answered, in part, by considering wealth.

\section{A. Wealth as the Measure}

As Oliver and Shapiro argue in Black Wealth/White Wealth, private wealth is a more appropriate indicator of inequality than income, education, or occupation, because "the command over resources that wealth entails is ... closer in meaning and theoretical significance to our traditional notions of economic well-being and access to life chances. ${ }^{, 69}$ According to Oliver and Shapiro, although "resources theoretically imply both income and wealth, the reality for most families is that income supplies the necessities of life, while wealth represents a kind of 'surplus' resource available for ... securing prestige, passing status along to one's family, and influencing the political process." ${ }^{30}$ If, for instance, wealth affords an individual the opportunity to acquire controlling ownership of a production facility, that individual is freed from authority structures and can enjoy occupational autonomy. Transfer of that wealth from generation to generation assures that the position of authority and opportunity remain in the same family; thus wealth enables one to account for cumulative advantage and disadvan-

\footnotetext{
Reliance on high school rank alone excludes fewer people from lower socioeconomic backgrounds. When the SAT is used in conjunction with high school rank to select college applicants, the number of applicants admitted from lower-income families decreases. This is because the SAT is more strongly correlated with every measure of socio-economic background than is high school rank.
}

Sturm \& Guinier, supra note 3, at 988-89. Noting the income/SAT correlation as well, Hacker attributes the lower performance of African Americans to their social isolation, which results in "less ... exposure to the rules of 'linear reasoning' that are expected on SAT and IQ tests." HACKER, supra note 59, at 151 . Thus, the emphasis of standardized test scores allows preferential allocation of higher education - a social component of full citizenship_excluding those who "develop alternative intellectual styles" in their isolation. Id.

68 "Most conservative Americans tend to disclaim responsibility for issues and tensions associated with race.... In their view, black Americans .... for at least a generation, have been given plenty of opportunities, so they have [only] themselves to blame for whatever difficulties they face." HACKER, supra note 59, at 55-56. Affirmative-action opponents attempt to prove that race-based remedies are no longer needed by pointing to success stories such as the growth of the African American middle class and the African American presence in key government positions and various professions that were once exclusively relegated to the white majority. But see id. at 112-13 (noting that, aside from entertainers, most African Americans holding prominent positions are employed by governmental or public service entities, and observing that "the private sector has been less welcoming").

${ }^{69}$ OLIVER \& SHAPIRO, supra note 57, at 2.

70 Id. at 32 . 
tage. ${ }^{71}$ Some who dispute the relation between wealth and economic power argue that the two do not equate because "individuals with relatively little wealth may ... nonetheless exercise considerable economic power because of their institutional positions." 72 This argument, however, presumes that those with power based on institutional positions are secure and bear no risk to their position regardless of the choices made in exercising their authority and influence. Such security is usually guaranteed by financial independence; thus the significance of wealth is inevitable.

Oliver and Shapiro demonstrate that income alone does not predict wealth. A comparison of income, net worth, and net financial assets for black and white, middle-class workers shows that, although blacks in the sample earned $70-85 \%$ of the income that whites earned, their net worth was only $16-31 \%$ of whites' net worth, and their net financial assets were zero. ${ }^{73}$ Further, a comparison of black and white net worth for various scenarios shows that there is a $74 \%$ differential in net worth between similar white and black households that cannot be explained by age, work experience, household size, or level of education. ${ }^{74}$ More importantly, because wealth encompasses resources and material assets that are transferred from generation to generation, thus having "historic origins," 75 a wealth-based analysis of racial inequalities underscores the justice in reparations for a historic wrong. ${ }^{76}$

${ }^{71}$ This intergenerational transfer of wealth is a critical factor in determining social status. This effect of wealth on generations is affirmed by looking at the backgrounds of the Nation's wealthiest men. See id. at 29 (stating that " $39 \%$ of the wealthiest men in America came from the upper social class in 1900 ; by $1950,68 \%$ of the richest men were born to wealth; and this figure climbed to $82 \%$ by 1970 ").

72 Id. at 31 .

73 See id. at 97 (stating that, for example, a married white middle class couple has an average income of $\$ 32,400$ and an average net worth of $\$ 65,024$, but a similarly situated black couple only has an average income of $\$ 25,848$ and an average net worth of $\$ 17,437$ ).

${ }^{74}$ See id. at 202, 209 (noting that among the variables included in the analysis were age, grade level completed, number of workers in the household, number of children in the household, and whether there was a white-collar worker in the household).

${ }^{75} \mathrm{Id}$. at 2.

${ }^{76}$ See id. at 160-70 (discussing how parental wealth affects net worth and net financial assets for whites and blacks); see also WEST, supra note 55, at 63 ("The urgent problem of black poverty is primarily due to the distribution of wealth, power and income-a distribution influenced by the racial caste system that denied opportunities to most 'qualified' black people until two decades ago."); infra Part IV.B (discussing reparations in the context of distributive justice). 


\section{B. Beneath the Surface Status Quo}

"[African American] conservatives and liberals alike ... contend that land and man's own self-contained sense of industry serve as the greatest emancipators and equalizers of people in America."77 As key routes to wealth, control of land and labor are cornerstones in a capitalistic society, where political empowerment is closely tied to economic empowerment. This connection between land/labor control and political voice manifests itself in voter districting ${ }^{78}$ and lobbying, both of which directly impact state and federal legislative and executive powers, which in turn control the appointment of judicial power. In areas where state and local judges are elected, the ramifications of land/labor control extend directly to the state judicial power. ${ }^{79}$ Thus, it is instructive to explore the connection between historical race biases against African Americans and the status quo of black/white inequalities by focusing on land ownership and entrepreneurship.

\section{Early Disenfranchisement}

At the close of the Civil War, four million former slaves emerged from "two and a half centuries of legalized oppression ... [to enter] Southern so-

${ }^{77}$ M. Leo Owens, Vanishing Farmsteads: An Issue of Ownership, in ABOUT . . TIME, July 1993 , at 10,11 .

${ }_{78}$ Traditional voter districting principles include geographic "compactness, contiguity, and respect for political subdivisions." Shaw v. Reno, 509 U.S. 630, 647 (1993). Thus, the ability to buy land in any district without restriction, as well as the ability to control the racial population of district areas, impacts the strength of any groups political voice. See, e.g., id. at 642 (holding that although race conscious redistricting is not per se violative of the Equal Protection Clause, "redistricting legislation that is so extremely irregular on its face that it rationally can be viewed only as an effort to segregate the races for purposes of voting, without regard for traditional districting principles and without sufficiently compelling justification" is violative); see also Lani Guinier, No Two Seats: The Elusive Quest For Political Equality, 77 VA. L. REV. 1413, 1513-14 (1991) (advocating an at-large voting scheme and legislative rules that allow cumulative voting and encourage consensus decisions to help equalize the position of minorities and other underrepresented groups); Steven J. Mulroy, The Way Out: A Legal Standard for Imposing Alternative Electoral Systems as Voting Rights Remedies, 33 HARV. C.R.-C.L. L. REV. 333, 339-43 (1998) (advocating the use of non-traditional systems of voting, such as cumulative voting, limited voting, and preference voting, to enhance minority representation).

79 This is the case in Alabama, Arkansas, California, Connecticut, Illinois, Indiana, Louisiana, Michigan, Missouri, North Dakota, Pennsylvania, South Carolina, Tennessee, Virginia, and Washington. See, e.g., ALA. CONST. amend. 328, $\$ 6.14$ (providing that "[v]acancies in any judicial office shall be filled by appointment by the governor"); ARK. CODE ANN. § 1617-103 (Michie 1994) ("The judge of a municipal court elected to that office by countrywide vote ... must be a resident of the county in which the court sits."). 
ciety with little or no material assets." ${ }^{90}$ The majority of slaves had been agricultural workers. ${ }^{81}$ An estimated half million had experience in mining, lumbering, railroad building, construction, and various craft occupations, and of these, about 50,000 were engaged in manufacturing. ${ }^{82}$ As previously discussed, the Confiscation Act failed to help the majority of freed slaves to secure land. ${ }^{83}$ However, in 1866, the Southern Homestead Act "did provide part of the basis for the fact that by 1900 one-quarter of Southern black farmers owned their own farms." ${ }^{84}$ Those that had not secured their own land entered the labor market; the competition was not welcomed by white laborers, who were unwilling to admit African American workers to their unions. ${ }^{85}$ African Americans without land or alternative means were forced to return to white-owned farms for meager monthly wages or a share of the crop. $^{86}$

Most Southern whites ... were convinced that laws should be speedily enacted to curb blacks and to ensure their role as a laboring force in the South. These laws, called Black Codes, bore a remarkable resemblance to the antebellum Slave Codes ... and can hardly be described as measures that respected the rights of blacks as free individuals. Several of them undertook to limit the areas in which blacks could purchase or rent property. Vagrancy laws imposed heavy penalties that were designed to force all blacks to work whether they wanted to or not. The control of blacks by white employers was about as great as that which slaveholders had exercised. Blacks who quit their jobs could be arrested and imprisoned for breach of contract. They were not allowed to testify in court except in cases involving members of their race. Numerous fines were imposed for seditious speeches, insulting gestures or acts, absence from work, violating curfew, and the possession of firearms. There was, of course,

${ }^{80}$ OLIVER \& SHAPIRO, supra note 57, at 13.

81 See MELVIN M. LEIMAN, THE POLITICAL ECONOMY OF RACISM: A HISTORY 24-26 (1993) (characterizing the plantation as the "vital economic unit of the Southern political economy").

${ }_{82}$ See id. at 26 (discussing slavery and non-agricultural development).

83 See supra notes 36-40 and accompanying text (discussing the Confiscation Acts of 1861 and 1862); see also OLIVER \& SHAPIRO, supra note 57, at 14-15 (discussing the failures and successes of land distribution during and immediately following the Civil War).

84 OLIVER \& SHAPIRO, supra note 57, at 15.

85 See FRANKLIN \& MOSS, supra note 5, at 232-37 (discussing economic adjustments and discrimination faced by the four million former slaves).

86 "Plantation wages ranged from $\$ 9$ to $\$ 15$ a month for men and from $\$ 5$ to $\$ 10$ for women, in addition to food, shelter, and fuel." Id. at 234. As sharecroppers, "former slaves were allowed from one-quarter to one-half of the cotton and corn; they were also provided with a house, fuel, and in some cases food." Id. White employers "anxious to secure labor at the lowest possible price" often entered into labor contracts with black workers only to disregard their own obligations and enforce these contracts against the black workers. See id. at 232 (noting that although one of the services provided by the Freedmen's Bureau was assistance to help black workers obtain and enforce fair contracts, this assistance was often unsatisfactory). 
no enfranchisement of blacks and no indication that in the future they could look forward to full citizenship and participation in a democracy. ${ }^{87}$

The enactment of Black Codes throughout various southern states effectively suppressed the free labor market. ${ }^{88}$ In response, Congress passed the 1866 Civil Rights Act, which provided that freed slaves born in the United States were citizens entitled to the same rights and privileges as white citizens. ${ }^{89}$ The Fourteenth Amendment, ratified in 1868, was designed in part to validate the Civil Rights Act of $1866 .^{90}$ Once overt legislative discrimination was outlawed, African American workers were able to command wages more in line with the value of their labor. ${ }^{91}$ African American workers began to migrate in search of better work and life opportunities. $^{92}$

Group migrations were significant for several reasons. First, such migrations were sometimes a form of political protest, one of the few forms of protest in which disenfranchised African-Americans could engage. African-Americans frequently deserted regions in response to lynchings and other forms of white lawlessness, or in response to unfavorable legislation. African-Americans would move to places where they were relatively well treated or had relatively good economic prospects. ${ }^{93}$

White employers lobbied for facially neutral laws in an effort to stop these migrations, because the ability to migrate gave great leverage to Afri-

87 Id. at 225.

88 See David E. Bernstein, The Law and Economics of Post-Civil War Restrictions on Interstate Migration by African-Americans, 76 TEX. L. REV. 781, 787-88 (1998) ("In an attempt to curtail the market for African-American labor ... states and municipalities passed 'Black Codes' that regulated African-American labor. The more severe laws practically recreated slavery for African-American agricultural workers by prescribing labor terms.").

89 These included the rights

to make and enforce contracts, to sue, be parties, and give evidence, to inherit, purchase, lease, sell, hold, and convey real and personal property, and to full and equal benefit of all laws and proceedings for the security of person and property, as is enjoyed by white citizens, and shall be subject to like punishment, pains, and penalties, and to none other....

Act of Apr. 9, 1866, ch. 31, 14 Stat. 27 (reenacted by the Enforcement Act of 1870, ch. 114, § 18,16 Stat. 140, 144 (1870)) (codified as amended at 42 U.S.C. $\$ \S 1981-82$ (1994)).

90 See ANDREw KulL, THE COLOR-BLIND CONSTITUTION 75 (1992) ("It was the demonstrable consensus of the Thirty-ninth Congress that section 1 of the Fourteenth Amendment 'constitutionalized' the Civil Rights Act of 1866.").

91 See Bernstein, supra note 88, at 788 (reporting that the removal of the Black Codes led to a rise in wages for African Americans commensurate with the actual worth of their labor).

${ }_{92}$ See id. at 783.

93 Id. (footnotes omitted). 
can American workers. ${ }^{94}$ Although some state supreme courts ruled that these statutes were unconstitutional, the U.S. Supreme Court held that they were constitutional, thereby "negatively affect[ing] the lives of millions of African-Americans." ${ }^{.95}$

\section{Entrepreneurship}

Self-employment or entrepreneurship is a means of social mobility that has become almost synonymous with the "American Dream." African American men are only $38 \%$ as likely as white men to be self-employed, ${ }^{97}$ and small businesses owned by African Americans account for approximately $2.4 \%$ of the Nation's corporations, partnerships, and sole proprietorships. ${ }^{98}$ In an effort to bolster arguments that any disadvantage African Americans now suffer is of their own making, affirmative-action opponents are apt to point to the success of other non-European ethnic groups-especially the Japanese, Korean, and Jewish communities-in using selfemployment as a means to social and economic progression. ${ }^{99}$ The problem with such a surface-level comparison is that it ignores the unique historic

94 See id. at 782-83, 793-99 (discussing the laws enacted in some states that taxed emigrant agents who worked to assist African American workers in finding and traveling to new opportunities).

95 Id. at 781; see William v. Fears, 179 U.S. 270 (1900) (holding that the emigrant agent tax was not unconstitutional because the law's discrimination was based on reasonable grounds and did not impermissibly interfere with freedom of transit or contract); Bernstein, supra note 88, at 801 (noting that although "[t] he Alabama and North Carolina Supreme Courts ... [declared] such laws ... unconstitutional," a challenge to the Georgia Supreme Court's decision to uphold that State's law, which imposed a tax on emigrant agents, led to the unfavorable Supreme Court decision). Emigrant agents, persons engaged in hiring laborers for employment outside their state of residence, played a major role in the migration of African Americans because they "lowered the information costs of migration by using their resources to advertise distant opportunities. Agents also often subsidized... [migration costs] by either paying for or advancing the money for ... train tickets" and "sometimes even retir[ing] debts their recruits owed to plantation owners." Id. at 782 (footnotes omitted).

96 See HACKER, supra note 59, at 113 (discussing the "small business" sector as a route to wealth and social status).

${ }^{97}$ See id. at 114. The data reported (for men) shows self-employment rates of $20.3 \%$ for Korean Americans and $12.9 \%$ for Iranian Americans-with both groups exceeding white Americans at 9.5\%. The statistics for other groups were 9.0\% for Cuban Americans, $8.5 \%$ for Japanese Americans, and $7.8 \%$ for Chinese Americans, compared to 3.6\% for African Americans, 3.7\% for Filipino Americans, and 3.4\% for Puerto Ricans. See id.

${ }_{98}$ See id. at 113 (noting that the majority of these businesses are local enterprises servicing African American clientele, and $85 \%$ of them are individually- or family-run).

99 See OLIVER \& SHAPIRO, supra note 57, at 45 (noting the frequent portrayal of African Americans as the "ethnic group with the lowest rate and degree of success in using selfemployment as a means of social mobility"). 
and still prevailing frustrations of African American entrepreneurial efforts. ${ }^{100}$

"Between 1867 and 1917 the number of [African] American enterprises increased from four thousand to fifty thousand." 101 Three powerful illustrations of early frustration thwarting that remarkable growth trend are the race riots of Tulsa, Rosewood, and Wilmington. ${ }^{102}$ The Tulsa riot took place in the Greenwood district known as "Black Wall Street," an area in which African Americans owned the land and independently operated the district's businesses, schools, and banks. ${ }^{103}$ The "district encompassed forty-one grocers and meat markets, thirty restaurants, fifteen physicians, five hotels, two theaters, and two newspapers. The black community also included many wealthy blacks who had invested in and profited from oil leases." 104 Reportedly, the 1921 Tulsa race riot lasted for three days, as whites "rampaged through the Greenwood district breaking into homes, looting businesses and attacking any black person they saw.",105 "At the height of the melee, bundles of dynamite were dropped from an airplane[,] ... destroying everything." 106 The resulting damage, in addition to fatalities, was the destruction of thirty-five city blocks, including 18,000 African American homes, businesses, and churches. 107 "Afterward, more than 4000 blacks were interned on fairgrounds in cattle and hog pens." ${ }^{.108}$ Many

${ }^{100}$ See id. ("This form of invidious comparison projects a whole range of 'positive' characteristics onto those who have been successful ... while casting African Americans as socially deficient and constitutionally impaired when it comes to creating flourishing businesses.").

101 Id. at 48 (quoting JOHN SIBLEY BUTLER, ENTREPRENEURSHIP AND SELF-HELP AMONG BLACK-AMERICANS: A RECONSIDERATION OF RACE AND ECONOMICS (1991)).

102 Overt racist violence against African Americans by whites was quite common from the turn of the century to the 1960s. See FRANKLIN \& MOSS, supra note 5, at 312-54, 469, 509 (providing historical reports of mob violence, lynchings, and property burnings).

103 See Robin D. Barnes, Blue by Day And White by (K)night: Regulating the Political Affiliations of Law Enforcement and Military Personnel, 81 IOWA L. REV. 1079, 1080 n.1 (1996) (referencing SCOTT ELLSWORTH, DEATH IN A PROMISED LAND: THE TULSA RACE RIOT OF 1921 (1982)).

104 OLIVER \& SHAPRO, supra note 57, at 49-50.

105 Cary Clack, What's The Interest Due On Justice?, SAN ANTONIO EXPRESS-NEWS, Nov. 3, 1996, available in 1996 WL 11503071 (reporting on the posthumous clearance of an African American man, J.B. Stratford, who had been accused of inciting the riot). Apparently the riot ensued when African Americans sought to protect an African American boy from being lynched because a white woman accused him of attacking her. See FrANKLIN \& MOSS, supra note 5, at 352 (describing the riot); OLIVER \& SHAPIRO, supra note 57, at 50 (same).

${ }^{106}$ Barnes, supra note 103, at 1080 n.1.

107 See OLIVER \& SHAPIRO, supra note 57, at 50 (writing that there was extensive property damage, and that many people were left dead or homeless); Clack, supra note 105.

${ }^{108}$ Barnes, supra note 103 , at 1080 n.1. 
of the district's members left the area, but some stayed and attempted to rebuild. $^{109}$

Rosewood, a relatively prosperous logging town of about 200 African Americans in western Levy County, Florida, was destroyed by a mob of white men who looted and killed, eventually burning down every home belonging to the blacks in the town. ${ }^{110}$ In Wilmington, North Carolina, according to one account, "there was grumbling among white professional classes' because ... 'black entrepreneurs, located conspicuously downtown, deprived white businessmen of legitimate sources of income to which they thought they were entitled."'111 The Wilmington Riot of 1898 "created an 'economic diaspora' in which black businessmen were forced to steal away in the night," eventually relocating "to Northern and Southeastern cities."112 These riots, all of which proceeded for days with no prohibitive state action, caused the demise of entire cities and business districts that were owned and populated by African Americans. ${ }^{113}$ The damage was not only the loss of life and property, but also the loss of opportunity to prosper in a networked environment, and the lost inheritance of future generations. ${ }^{114}$ Thus, although African Americans have enjoyed some success despite the odds, ${ }^{115}$

109

[W] hite city officials attempted to replace the ... [district] with a railroad terminal and other industrial facilities.... [and] adopted an ordinance requiring all new buildings in the area to be fireproof. The effect of the ordinance was to prevent some black Tulsans from rebuilding their burned homes where they had been because they could not afford to rebuild dwellings of two stories or more with the concrete, steel, or brick, required by the new ordinance.... [A] leading black attorney .... filed suit.... [and] persuaded a three judge panel to strike down the ordinance as an uncompensated taking of private property.

Paul Finkelman, Not Only The Judges' Robes Were Black: African-American Lawyers as Social Engineers, 47 STAN. L. REV. 161, 184-85 (1994) (book review) (footnotes and internal quotations omitted).

110 See Dan DeWitt, Revisiting Rosewood: Truth Be Told, ST. PETERSBURG TIMES, Feb. 21, 1997, at 1D. (reporting on the 1923 Rosewood massacre and its portrayal in a $1997 \mathrm{film}$ ).

111 OlIVER \& SHAPIRO, supra note 57, at 49 (quoting H. LEON PRATHER, WE HAVE TAKEN A CITY (1984)).

112 Id. at 49; see FRANKIIN \& MOSS, supra note 5, at 261 (discussing black disenfranchisement and patterns of violence at the turn of the century).

${ }^{113}$ See OLIVER \& SHAPIRO, supra note 57, at 49 ("Once home to flourishing black businesses .... these cities [where the riots happened] today retain no more than fleeting memories of a time ... washed away ... by the deadliest obstacle of all to black business, organized violence.").

${ }^{114}$ This is significant because of the ways in which nepotism, the "good ole boys network," and wealth accumulation by inheritance have favored whites.

115 One such example is the business section of Durham, North Carolina known as "Hayti." The Hayti district was home to North Carolina Mutual Insurance Company, a major African American corporation. See OLIVER \& SHAPIRO, supra note 57, at 48-49. By 1949, African Americans had established an enclave of over 300 businesses that served both African 
the instability of that success resulting from racist state policy, Jim Crow segregation, systemic discrimination, and outright violence has had a significant impact on efforts toward the economic empowerment of African Americans. ${ }^{116}$

\section{The Plight of African American Farmers}

Post-reconstruction efforts toward entrepreneurship and land acquisition have been largely thwarted by lack of capital and access to financing, as well as by limited access to information. In 1920, African Americans owned fifteen million acres of land and $17.4 \%$ of farm operators were black. $^{117}$ Today, however, African American farmers account for only 3\% of American farmers. ${ }^{118}$ As of 1991, African Americans owned less than four million acres of land, and, reportedly, face a possible annual average loss of fifty thousand acres resulting in a projected net loss of $\$ 2.5$ million. ${ }^{119}$ The decline is attributed to a "lack of capital needed to expand production capabilities through the purchase of increased acreage and new forms of technology." 120

American and white markets. Although 1960s urban renewal destroyed one-third of the businesses and 600 homes, the district still exists today. See id. (comparing the survival of Hayti with similar sections of Wilmington and Tulsa which were destroyed by organized violence).

${ }^{116}$ See Plessy v. Ferguson, 163 U.S. 537 (1896) (holding that a Louisiana statute that required racial segregation of railroad passengers was constitutional and reasonable under the circumstances), overruled by Brown v. Board of Educ., 347 U.S. 483 (1954); supra notes 88, 94-95 and accompanying text (discussing the Black Codes enacted in various states before and after the abolition of slavery); infra text accompanying notes 125, 132, 134 (discussing the racially biased implementation of government and institutional programs). As previously discussed, entrepreneurial efforts and property gains by African Americans were thwarted by white mob violence. See supra notes 102-12 and accompanying text (describing efforts at entrepreneurship and the resistance and violence by whites). Individual and organized racist acts by private citizens and by police officials permeate the experience of African Americans to this day. See, e.g., Nat Hentoff, Sunlight on Police Racism, WASH. PoST., Aug. 9, 1997, at A19 (describing two fatal instances of race-based police brutality against African American men and the beating of one grandmother, and noting that "[t]he extent of police brutality, especially against blacks, is not mentioned in any of the president's homilies on race relations"); Lola Smallwood, Cops Probe Dragging Of Black Teen, CHI. TRIB., June 14, 1998, at 4 (reporting that an African American "teenager was allegedly dragged several blocks by a ... vehicle [driven] by three white men yelling racial slurs," only days after "three suspected $\mathrm{Ku}$ Klux Klan members were arrested in Jasper, Texas" for dragging an African American man for two miles, causing a brutal death by dismemberment); Allan Turner, Racial Hate Crimes Sordid Part of State History, Hous. CHRON., June 14, 1998, at 10, available in 1998 WL 3582500 (citing four "high-profile" instances of racially motivated hate crimes against African American men in Texas by police and state troopers).

117 See Owens, supra note 77, at 10.

118 See id.

119 See id. at 10-11.

120 Id. at 11. 
Recently, the National Black Farmer's Association launched a "grassroots battle against more than three decades of documented discrimination by the U.S. Department of Agriculture ("USDA") and its employees."121 Programs designed fifty to sixty years ago, "to provide technical assistance to improve farm production, financial aid to help rural families acquire decent housing and economically viable farms, and price supports to protect farmers from the hazards of the market" have benefited white farmers to the detriment of African American farmers. ${ }^{122}$ Prior to the USDA's establishment of a nondiscriminatory policy for federal programs in 1964, African American farmers were largely unaware of these farm support programs and opportunities. ${ }^{123}$ Subsequently, although access to information has improved, access to available loan dollars has still been hindered by widespread discrimination. ${ }^{124}$ Based on investigations of the Farmers Home Administration ("FHA"), the USDA concluded that the FHA lending practices were influenced by "politics and racism." 125 The USDA has "frozen foreclosures on farms where the owner has filed a discrimination complaint" and legislation has been introduced "to prevent similar discrimination practices ... in the future. $" 126$

\section{Houses and Land}

"Housing is ... intimately connected with the quality of life since it is closely linked with education," health, and welfare-all social components of citizenship - as well as employment opportunities and income. ${ }^{127}$ Varied forms of racial discrimination in housing often exist in combination. ${ }^{128}$

${ }^{121}$ Kelley Smith, Black Farmers Have Beef With the USDA: Loan Denials Spark Legislation Proposal to Protect African American Farmers, BLACK ENTERPRISE, Jan. 1998, at $16,16$.

122 Valerie Grim, Black Participation in the Farmers Home Administration and Agricultural Stabilization and Conservation Service, 1964-1990, 70 AGRIC. HIST. 321, 321 (1996).

123 See id. at 322 (reporting that, prior to the civil rights movement, black farmers were "largely disconnected" from these loans programs).

124 See id. at 325-28 (reporting the severely low number and size value of loans made to African American farmers during the 1980s).

125 See id. at 329-30 (discussing how the FHA failed to achieve the goals of reaching out to minority farmers with information and help).

${ }^{126}$ Smith, supra note 121, at 16-17; see USDA Accountability and Equity Act of 1997, H.R. Res. 2185, 105th Cong. (1997) (proposing that both customers and employees of the Department of Agriculture be treated more fairly).

127 LEIMAN, supra note 81, at 135. "Housing discrimination ... creates de facto school segregation, which tends to reinforce racial economic differences." Id.

${ }^{128} \mathrm{See} i d$. at 136 (describing how "[t]hese multifarious forms of housing discrimination ... are not mutually exclusive, often existing in many combined forms for the individual"). 
They include more structurally substandard housing among blacks than whites; higher rent for black ghetto residents for equal or poorer facilities; three to four times more "overcrowding in the ghetto... which has been intensified rather than lessened by urban renewal"; 129 higher prices for merchandise sold to ghetto residents "caught in a captive market"; 130 compromised access to employment opportunities in expanding suburban industrial parks, as a result of barriers to acquiring suburban housing; and premiums charged to black homeowners seeking to buy into white or mixed areas. ${ }^{131}$ In addition, a disproportionate share of hazardous waste landfills and facilities are located in areas predominately populated by African Americans. ${ }^{132}$

Another prevalent form of housing discrimination against African Americans is banking discrimination and redlining. ${ }^{133}$ "A 1991 Federal Reserve study of 6.4 million home mortgage applications by race and income confirmed suspicions of bias in lending by reporting a widespread and systemic pattern of institutional discrimination in the nation's banking system." 134 This study showed that African American applicants are denied loans two to three times more often than white applicants; high-income African Americans are declined loans more often that low-income whites; mortgage rates for African Americans are 5.4 points higher for federal program loans, and 9.2 points higher for conventional loans compared to

${ }^{129}$ Id.

131 See $i d$. (noting that "the greater difficulty of acquiring housing in the suburban areas cut many blacks off from employment opportunities in the expanding industrial parks in the suburbs"); see also Michelle Adams, Separate and [Un]equal: Housing Choice, Mobility, and Equalization in the Federally Subsidized Housing Program, 71 TUL. L. REV. 413, 427-30 (1996) (discussing the specific kinds of harm caused by pervasive housing discrimination against African Americans).

132 See Alice L. Brown, Environmental Justice: Constitutional and Statutory Challenges to Environmental Racism, in AFRICAN AMERICANS AND THE LIVING CONSTITUTION 270, 272-74 (John Hope Franklin \& Genna Rae McNeil eds., 1995) (discussing the findings of several studies that show evidence of environmental racism).

For instance, a study of municipal incinerators and municipal and private landfills concluded that although African Americans constituted only 28 percent of the population of Houston, Texas, in 1980, six of the city's eight incinerators, five of the six state-permitted municipal landfill sites, and all five of the unpermitted municipal landfill sites were located in predominately African American neighborhoods.

Id. at 273. Furthermore, there is substantial evidence that the Environmental Protection Agency, a federal agency, "discriminates against minority communities in the cleanup of hazardous waste sites." Id. (discussing the findings of an investigation of U.S. environmental lawsuits from 1985 to 1991) (citing Marianne Lavelle \& Marcia Coyle, Unequal Protection: The Racial Divide in Environmental Law, NAT'L L.J., Sept. 21, 1992, at S2).

${ }^{133}$ See OLIVER \& SHAPIRO, supra note 57, at 19 (describing how banking discrimination and redlining used to be confined to African Americans seeking to buy homes in white areas, but now affects African Americans seeking to buy homes anywhere).

${ }^{134}$ Id. 
whites; and these trends are present regardless of the area in which African Americans seek to buy homes. ${ }^{135}$

\section{The Effect on Full Citizenship}

"The essence of equal [or full] citizenship is the dignity of full membership in the society." 136 This membership necessarily entails a civil or legal component, a political component, and a social component. ${ }^{137}$ The civil component refers to an individual's security in the basic rights and liberties derived from the societal values reflected in the Bill of Rights and the Fifth and Fourteenth Amendments: the right to secure one's self and property; freedom of speech, religion, assembly, and association; and "both substantive and procedural equality before the law."138 The political component is essentially democratic enfranchisement-participation in the governmental process through the right to a "formal voice in the selection of leadership" and the right to "attempt to influence policy."139 The social component concerns welfare and general well-being, or those resources and capacities required to secure the "opportunity to express and implement the [civil and political] rights derived from ... societal values."

The social component includes health, education, and welfare, and "presumptively forbids the organized society to treat an individual ... as a member of an inferior or dependent caste or as a nonparticipant."14i Thus, the social component addresses social status. ${ }^{142}$ Theoretically, "the societal

${ }^{135}$ See id. at 137, 142 (highlighting the differential treatment of African Americans in obtaining mortgages and loans).

${ }^{136}$ Kenneth L. Karst, The Supreme Court 1976 Term-Foreword: Equal Citizenship Under the Fourteenth Amendment, 91 HARV. L. REV 1, 5 (1977).

137 See id. (discussing citizenship and equal protection under the 14 th Amendment, as well as under the Fifth Amendment as it pertains to federal limitations); Parsons, supra note 12 , at 1009, 1017 (analyzing the inclusion problem for African Americans as compared to other groups that have faced discrimination in America).

${ }^{138}$ Parsons, supra note 12, at 1017. "These rights are to take precedence over any particular political status or interest and over any social component such as wealth or poverty, prominence or obscurity." Id.

${ }^{139} I d$.

140 Id. at 1017-18.

141 Karst, supra note 136, at 6; see Parsons, supra note 12, at 1017 (specifying the elements of health, education, and welfare).

142 Karst presents a "well-being" perspective of equal citizenship. He posits that the principle of equal citizenship embodies "an ethic of mutual respect and self-esteem," Karst, supra note 136, at 6 (quoting JOHN RAWLS, A THEORY OF JUSTICE 256 (1971)), and "guards against degradation or the imposition of stigma," $i d$., because the "relationship between stigma and inequality is . . clear: while not all inequalities stigmatize, the essence of any stigma lies in the fact that the affected individual is regarded as an unequal in some respect." Id. Here, stigma is defined not by "the subjective reaction of one who feels stigmatized, but 
community defines and presents standards for the allocation of resources to the community as a whole."143 That allocation translates into "the definition of the terms on which capacities, as matched with opportunities, can be involved in the process of inclusion."

In practice, white males with wealth and influence have controlled this process. Consequently, the creation and protection of full citizenship depends on not only the formal equality of legal and political rights, but also on the prohibition of the subtle disenfranchisement that would render those rights moot. ${ }^{145}$ Underlying the concept of full membership in a societal community is the notion of "solidarity or mutual loyalty of its members" and a sense of "commitment of the members to the collectivity in which they are associated."146 For Americans, this notion translates into a national patriotism that supersedes state and local affiliations, as well as a mutual respect and priority for each individual's rights, regardless of the individual's race, ethnicity, or gender.

The prevailing condition for African Americans, however, is one of exclusion, not inclusion. Illustrations in the context of education alone include the proven bias of standardized tests used in university admissions; ${ }^{147}$ the poor quality of public education in predominately African American com-

by the attitudes of the general society, or a significant portion of society, toward persons with a particular characteristic." Id. at 6 n.25. Karst describes the "injurious effects of stigmatizing inequalities [as] both psychological and tangible.... [If internalized] as an index of personal worth, [inequality] directly harms the [Rawlsian] primary good of self-respect." Id. at 6-7. This analysis is similar to that which the Warren Court adopted in Brown v. Board of Education: "To separate [children in grade and high schools] from others of similar age and qualifications solely because of their race generates a feeling of inferiority as to their status in the community that may affect their hearts and minds ... [and] 'motivation ... to learn."' 347 U.S. 483, 494 (1954) (citation omitted).

143 Parsons, supra note 12, at 1018.

144 Id. A ready example of this is the use of standardized tests by most colleges and universities and some employers, to assess the qualifications of applicants. See, e.g., Sturm \& Guinier, supra note 3, at 983-96 (discussing the underinclusiveness of standardized tests used for college, law school, and employment).

145 See FONER, supra note 7, at 133 (noting that immediately following the abolition of slavery, Thaddeus Stevens, who was a congressional advocate for equal rights for African Americans, did not support the immediate grant of voting rights). Foner states that "Stevens ... challenged the idea that the impoverished and despised former slaves could immediately become independent voters" without first being "given the economic wherewithal to establish their independence from economic coercion." Id.

146 Parsons, supra note 12, at 1009-10.

147 See Sturm \& Guinier, supra note 3, at 988-89 (showing data that demonstrates that for each racial and ethnic group and gender, the "[a]verage family income rises with each 100 point increase in SAT scores, except for the highest SAT category where the number of cases is small]"' (footnote omitted)). 
munities; ${ }^{148}$ and the monocultural emphasis in educational materials that neglects the African American presence and contribution. ${ }^{149}$ Statistics reflecting disproportionate numbers of African American prisoners, ${ }^{150}$ disparate sentencing, ${ }^{151}$ and lingering blatant discrimination in the private and government sectors ${ }^{152}$ call into question even the surety of the civil component of full citizenship, substantive and procedural equality before the law. Further, the political component has been and still is retarded by the nullifying effects of various voting practices on the African American vote and a stifled African American participation in the lobbying process. ${ }^{153}$ Thus, African Americans as a group still do not enjoy the dignity of full membership in the American community.

148 See generally JONATHAN KOZOL, SAVAGE INEQUALITIES: CHILDREN IN AMERICA'S SCHOOLS 83-132 (1991) (describing a case study of inequalities in public education in New York).

149 See, e.g., HACKER, supra note 59, at 172-73 (discussing the domination of the "EuroAmerican monocultural perspective" in school curricula).

150 See id. at 246 (listing the ratio of African American prisoners to the African American population as approximately 3.8 for the Nation, and between 4 and 18 for the 13 states above the national ratio).

${ }^{151}$ See McClesky v. Kemp, 481 U.S. 279, 312-13 (1987) (considering evidence of racial disparities in death penalty sentencing).

152 See, e.g., supra note 18; infra notes 171-73 and accompanying text (documenting the increase in employment discrimination despite the existence of affirmative-action programs).

153 See Luis Fuentes-Rohwer, Note, The Emptiness Of Majority Rule, $1 \mathrm{MICH}$. J. RACE \& L. 195, 210-11 (1996) (discussing various voting practices that were developed to circumvent the letter and spirit of the Voting Rights Act).

"Candidate diminution," as an example, involved the abolition of political offices, the extension of terms for White incumbents, and the imposition of "stiff formal requirements for qualifying to run in primaries or general elections, e.g., high filing fees, numerous nominating petitions or complex oaths." Another such practice, that of vote dilution, was just as perverse. Some of its manifestations included: racial gerrymandering; decreasing the black proportion in a town or county by annexation, deannexation, or consolidation; imposing a majority runoff requirement, which can enable white voters to mobilize behind a single white candidate in the runoff after having split their votes among several whites in the first election; holding at-large rather than district elections, which allows white voters to overwhelm black ones when the latter are in the minority; enacting such devices as full-slate laws, numbered-place laws, and staggered terms, all of which can, under some circumstances, preclude the use of "single shot" voting by blacks, a strategy that can help them in at-large systems to elect black candidates; and "splitting the vote for a strong black candidate by nominating additional blacks as 'straw' candidates for the same office." Id. (footnotes and citations omitted). For examples of empowering alternatives to these practices, see Guinier, supra note 78, and Mulroy, supra note 78. 


\section{WHY REPARATIONS?}

You do not take a person who, for years, has been hobbled by chains and liberate him, bring him up to the starting line of a race and then say, "you are free to compete with all the others," and still justly believe that you have been completely fair. ${ }^{154}$

President Clinton's charge to the Race Advisory Board narrows the focus to "recent ... race relations," suggesting that the racial tensions that exist today have little to do with American history that is not "recent."155 Affirmative action is preferred over revisiting the past. ${ }^{156}$ Affirmative action has been helpful in forcing access for a small number of individuals to certain educational and economic venues, but it does not effectively level the playing field for African Americans as a collective race. ${ }^{157}$ Indeed, one general justification for affirmative action, as a "corrective for the continuing effects of past discrimination," is that, "against the backdrop of a terrible history of oppressive color conscious discrimination[,] ... immediate colorblindness would perpetuate exclusion and be unfair."158 Given the historical severity of the black-white relationship, is it really feasible to move forward without looking back? Or is healing the racial divide, without addressing the underlying sources of racial animosities, as unlikely as healing a festering wound by applying bandages, without first cleaning away the infectious pus? Seemingly, these questions are rhetorical. Nevertheless, although apologies and reparations have been extended for lesser atrocities, ${ }^{159}$ the idea of extending the same to African Americans for slav-

154 President Lyndon B. Johnson, To Fulfill These Rights, Speech at Howard University Commencement (June 4, 1965), reprinted in LEE RAINWATER \& WILLIAM L. YANCEY, THE MOYNIHAN REPORT AND THE POLITICS OF CONTROVERSY 125, 126 (1967).

155 See Exec. Order No. 13,050, 3 C.F.R 207, 207-08 (1997) (directing the President's Advisory Board on Race to "[i]ncrease the Nation's understanding of our recent history of race relations").

${ }^{156}$ See, e.g., Clinton Refuses Reparations for Slavery, Clinton Calls for 'Repairing, 'Not Repaying, FLA. TODAY, June 17, 1997, at 3A, available in 1997 WL 11480352 [hereinafter Clinton Refuses Reparations] (reporting President Clinton's preference for continued affirmative action in the absence of an effective alternative).

157 See WEST, supra note 55, at 63 ("[D] e facto affirmative action measures ... [such as] contracts, jobs[] ... subsidies to certain farmers[, and] FHA mortgage loans to specific homebuyers... have been based on preferential policies.... [that] benefit middle-class Americans disproportionately.").

158 EDLEY, supra note 19, at 77 (quoting a memorandum on affirmative action from Professor Paul Gewirtz of the Yale Law School to President Clinton and others).

159 See supra Part IV.C (discussing reparations to Japanese Americans and Aleuts). In May 1997, President Clinton apologized, on behalf of the United States government, to survivors of "The Tuskegee Study of Untreated Syphilis in the Negro Male." See Carl M. Cannon, Survivors of Tuskegee Study Get Apology, BALTIMORE SUN, May 17, 1997, at 1A, available in 1997 WL 5511866 (reporting that, since the government had already paid court-ordered 
ery and the related continuing discrimination is still met with resistance, despite President Clinton's acknowledgment and informal apology to subSaharan Africa for America's part in the slave trade. ${ }^{160}$ One articulation of the reluctance is that " ' $[\mathrm{i}] \mathrm{t}$ 's been so long, and we're so many generations removed",; 161 another expressed reluctance, which has also been stated in opposition to affirmative action, is that African American reparations would do more to incite racial tensions than to resolve them. ${ }^{162}$ Both excuses ignore the equitable rationale for the continuing-wrongs doctrine- "when [wrongful] conduct continues[,] ... repose is outweighed by the interest in securing compensation for serious harm." 163 The latter "public popular consensus" rationale ignores the power of Congress and the judiciary to rectify even that which the majority population seeks to uphold-the very power

damages, the apology was "intended ... to set a tone of redemption for Clinton's foray into the often explosive area of racial disharmony").

In no way is the reference to "lesser atrocities" meant to belittle the experience of the Japanese American, the Aleuts, or the Tuskegee experiment victims. The point here is to underscore the weakness of a policy that selectively addresses some past harms, but glosses over the continuum of harms to African Americans, based on a rationale that the magnitude of the damages for African Americans is just too great.

${ }^{160}$ House Concurrent Resolution 96, introduced in June 1997, calls for an apology to African Americans whose ancestors suffered as slaves under the Constitution and laws of the United States until 1865. See H.R. Con. Res. 96, 105th Cong. (1997). During President Clinton's recent visit to various sub-Saharan African nations, the President spoke in Uganda about how wrong America was to be involved in the slave trade. See Nancy Mathis, President Acknowledges U.S. 'Sins' Against Africa, HOUSTON CHRON., Mar. 25, 1998, at 1A, available in 1998 WL 5084860. However, the same expression on American soil does not appear to be forthcoming:

[M]ost of my African American friends and advisors don't believe that we should get into what was essentially a press story about whether there should be an apology for slavery in America. They think that that's what the 13th, 14th, and 15th amendment was [sic]; they think that's what the civil rights legislation was; and they think we need to be looking toward the future.

Interview by Ebony, Jet, and American Urban Radio Network with President William J. Clinton, Cape Town, South Africa (Mar. 27, 1998), available in 1998 WL 158707 (quoting President Clinton's answer to a question about his emphatic resistance to apologizing to African Americans for slavery).

${ }^{161}$ Clinton Refuses Reparations, supra note 156 (quoting Interview by Urban Radio Network with President William J. Clinton (radio broadcast, June 16, 1997)); see also Verdun, supra note 7, at 607 (noting perceptions that current-day African Americans do not deserve reparation, since all ex-slaves are dead and current day "white Americans living today have not injured African Americans and should not be required to pay for the sins of their slavemaster forbearers").

${ }^{162}$ See OLIVER \& SHAPIRO, supra note 57, at 189 (noting that among the objections to reparations is that "[t]hey may inflame more racial antagonism than they extinguish").

${ }^{163}$ Peggy L. Miller, Repeated Wrongs Do Not Make a Right: Continuing-Wrong Doctrine \& Personal Injury Claims, 9 T.M. COOLEY L. REV 369, 376-77 (1992). 
that the Supreme Court confirmed in the racial context in Brown v. Board of Education. ${ }^{164}$

\section{A. Race-Neutrality, Meritocracy, and Remediation}

Presumably, merit is understood as achievement based on functional capacity ${ }^{165}$-or intellect and hard work. Three elements at the core of the "moral claim for the merit principle" are: maximization of efficiency and social welfare; entitlement to decisions based on "individual desert" and "personal qualities," rather than "social or political conventions tied to group identity"; and alignment of "incentives so as to promote and reinforce both autonomy and personal responsibility." 166 This argument, however, is flawed in several respects. Two problems with the meritocratic argument are that: first, it wrongly assumes that merit is something that can be consistently measured between individuals under any circumstances; ${ }^{167}$ and second, it assumes that all have fair access to opportunity, dismissing the evidence that, as a collective, African Americans continue to suffer harms of past and present discriminations. ${ }^{168} \mathrm{~A}$ third problem is that the meritocratic argument ignores the relation between economic empowerment and political empowerment, and thus fails to address the problem of access to full citizenry. ${ }^{169}$ In actuality, each individual's access to success and wellbeing in a capitalistic economy is tied to the accumulated wealth and opportunities enjoyed by past generations, both of which directly impact political influence. ${ }^{170}$

164347 U.S. 483,495 (1954) (holding that segregation in public schools violated the 14th Amendment right to equal protection despite popular and state government support for segregation).

Cf. Sturm \& Guinier, supra note 3 , at $968-80$ (challenging "the claim that the conventional 'meritocracy' functions to identify those who can best perform").

166 EDLEY, supra note 19, at 143 (emphasis omitted).

167 See id. at 80, 143-50 (discussing the true complexity of merit and opportunity); Sturm \& Guinier, supra note 3, at 1035 (asserting that proponents of merit-based decision making erroneously equate high numerical rankings with merit).

168 Hearings on H.R. 2128, supra note 19, at 132 (testimony of Jorge Amselle, Communications Director, Center for Equal Opportunity) (arguing that the justification of affirmative action as historical reparations "is applicable almost exclusively to Blacks only [and] ... ignores the reality that not all Blacks are still suffering from the effects of America's shameful past").

169 See Rhonda V. Magee, The Master's Tools, From the Bottom Up: Responses to African American Reparations Theory in Mainstream and Outsider Remedies Discourse, 79 VA. L. REV. 863, 875 (1993) (discussing the ideal society reforms "necessary to ensure the representation of African-Americans of all economic classes within political debates").

${ }^{170}$ See supra text accompanying notes $69-76$ (discussing intergenerational wealth and the relation between economic power and political power). 
A clear warning of the inevitable failure of meritocracy in a society still prone to racial discrimination comes from tester studies in which black and white applicants are given identical fabricated credentials and sent on interviews seeking employment, loans, or housing. Studies showed that, even for blue-collar jobs, black applicants were $20-25 \%$ less likely to advance in the hiring process. ${ }^{171}$ Black applicants also faced discrimination in contacts with realtors, ${ }^{172}$ and are declined for loan approvals at disparate rates. ${ }^{173}$ Despite any claim to the contrary, white Americans simply have an unfair advantage over African Americans that bears no relation to their individual character or qualifications.

Thus, a true meritocracy cannot be achieved unless everyone starts with a clean slate or, at least, a fair allocation of the basic resources that ensure full citizenship. ${ }^{174}$ "Affirmative action is not the most important issue for [African American] progress in America, but it is part of a redistributive chain that must be strengthened if we are to confront and eliminate black poverty [and disenfranchisement]."175

\section{B. The Moral Economy Incentive $e^{176}$}

If "the success of the moral economy of restitution"177 is measured "by the degree to which it enables the victims to claim a share of the economic pie ... and legitimize their side of history,"178 then America cannot achieve

171 See EDLEY, supra note 19, at 48-49 (citing tester case results from studies conducted by the Fair Employment Council of Greater Washington during 1990-92 and the Urban Institute's Employment and Housing Discrimination Studies in 1991).

${ }_{172}$ See id. at 49 (noting that the Urban Institute's study revealed discrimination in "roughly half of all contacts" for African Americans and discussing research conducted by the Justice Department that documented numerous instances in which white applicants were shown apartments after black applicants had been told that there were no vacancies).

${ }^{173}$ See supra notes 123-25, 133-35 and accompanying text (discussing discrimination in governmental loans and grants to African American farmers and would-be homeowners).

${ }_{174}$ Admittedly, a "clean slate" is radical; but redistribution to ensure access to full participation and the basic liberties that come with full citizenship is not.

${ }_{175}$ WEST, supra note 55 , at 65 .

${ }^{176}$ In a moral economy, restitution "attempts to rectify historical injustices and facilitate higher awareness of public morality through the use of market mechanisms." Barkan, supra note 1 , at 53 . The rationale works when a recognition of both parties' histories would be beneficial and lead to the transfer of economic resources. See id. "[A]greements ... are entered into voluntarily.... [But] this willingness ... often results from political pressure, or exhaustion from a prolonged conflict." Id. at 54 . The goal in every case is reconciliation. See id.

${ }^{177} \mathrm{Id}$ Id. 
an equitable multicultural society without granting reparations to African Americans. ${ }^{179}$

Whether through active military involvement, international trade sanctions, or diplomatic mediation, the U.S. government has a history of actively advocating human rights and democracy in the international arena. Increasingly, the principle of restitution is forming the "basis for a new worldwide moral economy, $" 180$ in which the empowered global market supports restitution as moral atonement for "wrongs of one people against another."181 A familiar example of the global trend toward nations compensating victims because of political pressure is the German grant of reparations to Jewish Holocaust survivors. ${ }^{182}$ A more recent example is Japanese reparations to Korean "comfort women." 183 There has also been a rash of public apologies: from President Clinton to native Hawaiians; from Poland to Jews for a massacre in 1946; from Canada to CanadianUkrainians for maltreatment during World War I. ${ }^{184}$

Quite significant is President Clinton's apology to sub-Saharan African nations for the role of the United States in the slave trade. ${ }^{185}$ The timing of this apology and the African Growth and Opportunity Act is reminiscent of the circumstances surrounding the reparations for Japanese Americans and

179 See id. at $54,57$.

180 Id. at 52.

181 Id. at 52. See generally THEO VAN BOVEN ET AL., SEMINAR ON THE RIGHT TO RESTITUTION, COMPENSATION, AND REHABILITATION (1992) (including various writings that discuss rights of victims who have suffered gross violations of human rights and fundamental freedoms).

${ }^{182}$ See generally NANA SAGI, GERMAN REPARATIONS: A HISTORY OF THE NEGOTIATIONS (1980) (tracing the negotiations between Jewish survivors and Germany before and after World War II). The United States has also intervened to secure reparations for Jewish Americans. See Princz v. Federal Republic of Germany, 26 F.3d 1166, 1168 (D.C. Cir. 1994) (noting the intervention by the U.S. Department of State, the New Jersey congressional delegation, and the Clinton administration on behalf of one Jewish American); see also Grunfeder v. Heckler, 748 F.2d 503, 509 (9th Cir. 1984) (holding that reparations payments from Germany to Holocaust survivors do not constitute income for the purpose of determining Social Security Insurance benefits).

${ }^{183}$ Cf. Shibata Tetsuji, Japan's New Nationalism: It Has Wide Sources of Support and Uses the Media Well, ASIAWEEK, May 23, 1997, available in 1997 WL 10819277 (noting that in 1993 the Japanese government apologized for "this past action" and allocated funds to be distributed to every victim).

${ }^{184}$ See Barkan, supra note 1, at 55 (noting that "the most egregious injustices remain in the collective memory").

${ }^{185}$ See supra note 160 (discussing President Clinton's apology during his visit to subSaharan African nations). 
"pro-Japan trade policies." "For Congress, lingering animosity over the [internment] of Japanese-Americans during World War II may have been viewed by some as a barrier to effective economic relations between Japan and the United States."187 Similarly, the coincidence of President Clinton's apology with the African Growth and Opportunity Act is, perhaps, the epitome of bartering guilt for economic gain because the Act provides for a "new trade and investment policy for sub-Saharan Africa."188 Furthermore, the African Growth and Opportunity Act includes a provision deeming ineligible those countries that are "determined by the President to engage in a consistent pattern of gross violations of internationally recognized human rights." 189 Absent at least a symbolic atonement for slavery, the United States could not seek to impose such a moral provision regarding trade with Africa without appearing hypocritical. The apology to Africa, however, is meaningless without redress for African Americans. It would be a double standard if America does not grant reparations to African Americans who have suffered through the many dehumanizing experiences that litter the African American experience.

\section{IN SUPPORT OF LEGISLATION}

While [African Americans] may be justified in seeking redress for past and present injustices, it is not within the jurisdiction of this Court to grant the requested relief. The legislature, rather than the judiciary, is the appropriate forum for plaintiff's grievances. 190

\section{A. Procedural Barriers to Individual Suits}

As there is no statutory ground for pursuing African American reparations through the courts, the alternative lies in tort. In theory, there are several potential tort suit scenarios. The plaintiff could be an individual Afri-

186 See Magee, supra note 169, at 909 ("The favorable congressional response to the Japanese-American case for reparations unfolded contemporaneously with the pro-Japan trade policies of the Reagan Administration.").

187 Id. at 908-09.

188 See H.R. 1432, 105th Cong. (1998). Unfortunately, the African American case for reparations currently lacks the support of an empowered player in the global economy that could provide the exterior political incentive for the.United States to pass the African American reparations legislation. See Magee, supra note 169, at 909 (noting that "no leverage-laden tie to political or economic power exists between the descendants of American slaves and a 'first world' economic power').

${ }^{189}$ H.R. 1432 § 4(d).

190 Cato v. United States, 70 F.3d 1103, 1105 (9th Cir. 1995) (quoting dicta from Judge Armstrong's district court order of dismissal). 
can American or a class of African Americans. The defendant could be an individual white American, a class of white Americans, the government as a surrogate for white Americans, ${ }^{191}$ or the government as a wrongdoer in its own right. A suit in tort for African American reparations, however, is plagued with procedural problems that have proven dispositive. ${ }^{192}$ Some of the problems were illustrated by the first federal appellate court case to be heard on African American reparations-Cato v. United States. In Cato, the plaintiffs sued the United States seeking damages for past and present injustices related to ancestral slavery. They also sought an acknowledgment of and apology for discrimination against freed slaves and their descendants from the end of the Civil War to the present. ${ }^{193}$ The Ninth Circuit affirmed the district court's dismissal, finding that the complaint did not state a legally cognizable claim and could not be cured by amendment. ${ }^{194}$

Without consent to suit in an action to which the federal government is a party, federal jurisdiction is limited to those claims "arising under the Constitution, laws, or treaties of the United States." 195 Moreover, sovereign immunity bars any suit against the United States, unless a waiver is "une-

191 For a discussion of the government as a surrogate for individual wrongdoers, see generally RAWLS, supra note 142.

192 See Cato, 70 F.3d at 1110-11 (dismissing a reparations claim for lack of an arguable basis in law, lack of federal jurisdiction, and preclusion by sovereign immunity); Trice v. United States, No. C 94-1474 BAC, 1994 WL 225179, at *2 (N.D. Cal. May 6, 1994) (same); see also Hohri v. United States, 586 F. Supp 769, 783, 786 (D.C. Cir. 1984) (holding that multiple claims in a class-action suit for reparations to former Japanese American internees were barred by the doctrine of sovereign immunity and/or the statute of limitations).

${ }^{193}$ See Cato, 70 F.3d at 1106 (describing the complaint as seeking compensation "for forced, ancestral indoctrination into a foreign society; kidnapping of ancestors from Africa; forced labor; . . . removal of traditional values; deprivations of freedom; and imposition of oppression, intimidation, miseducation and lack of information about various aspects of their indigenous character"). The complaints in Cato and Trice mirrored the language of the proposed bill for African American reparations, which had been introduced to Congress three times at the time these suits were filed. See Commission to Study Reparation Proposals for African Americans Act, H.R. 40, 105th Cong. \$ 2(b) (1997).

194 See Cato, 70 F.3d at 1106, 1111 (affirming the district court's dismissal of Cato's complaint). Cato had filed pro se, in forma pauperis on behalf of herself and three other family members, so the court dismissed the complaint under 28 U.S.C. § 1915(d) (1994). See Cato, 70 F.3d at 1105, 1106, 1111.

19528 U.S.C. $\$ 1331$ (1994). The "treaty" language eliminated the jurisdictional issue for most Native American claims for restitution. This is an important distinction which has precluded the use of Native American reparations as precedent for African American reparations. See Cato, 70 F.3d at 1108.

[T]here is nothing in the relationship between the United States and any other persons, including African American slaves and their descendants, that is legally comparable to the unique relationship between the United States and Indian Tribes. Courts have recognized fiduciary responsibilities running from the United States to Indian Tribes because of specific treaty obligations and a network of statutes .... 
quivocally expressed."'196 Even under the Federal Tort Claims Act, which gives federal courts jurisdiction over civil actions against the United States "for money damages, accruing on and after January 1, 1945,",197 a tort claim based on slavery would be barred unless the plaintiff could show: (1) that the continuing violations doctrine applies because African Americans are still impacted by the legacy of slavery and subsequent systemic discrimination; ${ }^{198}$ and (2) continuing wrongful acts by the government. ${ }^{199}$

Without the government as a defendant, "rights theory has made traditional remedies law a virtual obstacle course for racial remedies theorists. ${ }^{200}$ Generally, we ${ }^{201}$ believe group responsibility and group entitlement are not appropriate when "individuals are defined and treated as part of a group whose behavior they do not necessarily endorse or have significant control over." 202 This is especially so when the group is defined by an immutable characteristic such as race. ${ }^{203}$

Verdun's analysis of the rights theory in terms of the dominant (white American) perspective versus the African American consciousness provides an interesting synopsis of why the standing doctrine and causation doctrine are barriers to African American reparations suits in tort. ${ }^{204}$ The dominant

196 United States v. Mitchell, 445 U.S. 535, 538 (1980) (quoting United States v. King, 395 U.S. $1,4(1969))$.

19728 U.S.C. $\$ 1346($ b) (1994).

198 Title 28 of the U.S. Code, $\S 2401$ (b), bars any claim against the United States not brought within two years after the accrual of the harm. See 28 U.S.C. $\S 2401$ (b) (1994). Therefore, in order to avoid this statute of limitations problem, the plaintiff must utilize the continuing wrong doctrine. Under the doctrine, it is not enough that the harm continues, but rather "there must be a continuing wrongful act ... [and] a continuing relationship to establish an on-going duty and breach of that duty." Miller, supra note 163, at 376. "[T] he continuing-wrong doctrine has been embraced where it logically applies, and rejected when it does not," so that it has traditionally applied to allow recovery for tortious conduct causing property or personal injury claims. Id. In Cato, the Court recognized the applicability of this doctrine to the slavery-based claim; however, the court refused to rule on the doctrine's applicability to the case as presented. See Cato, 70 F.3d at 1108-09.

199 For an argument for reparations based on continuing governmental violations of 42 U.S.C. § 1983, see BORIS I. BITKER, THE CASE FOR BLACK REPARATIONS (1973). But see Magee, supra note 169, at 903 (criticizing Bitker for failing to counter the problems of sovereign immunity, the 11 th Amendment, standing, ripeness, and statue of limitations).

200 Magee, supra note 169 , at 907.

201 Here, "we" is the "broad American legal and non-legal populus."

202 FISCUS, supra note 67, at 9.

203 See id. (stating that general beliefs do not approve of group entitlements, especially when individuals are not free to withdraw from that group).

${ }^{204}$ See Verdun, supra note 7, at 619-29 (describing the independent perspective as one of individualism and self-determination and comparing that with the African American perspective that focuses on group identification); $c f$. Mari J. Matsuda, Looking to the Bottom: Critical Legal Studies and Reparations, 22 HARV. C.R.-C.L. L. REV. 323, 375 (1987) (naming the 
group embraces the rights theory and "perceives that each individual is responsible for his or her own behavior."205 From their perspective, vicarious liability for the actions of others is only applicable where the person assuming responsibility has control over the offender; if no such control relationship exists, then there is no legal or moral responsibility for the actions of others. ${ }^{206}$ In contrast, Verdun posits that, "African American consciousness emphasizes the significance of group identification.... Cooperation through collective efforts is the accepted means of achieving culturally prescribed goals."207 Verdun argues that society at large is the appropriate wrongdoer, because "[s]ociety, propelled by a set of values that were manifested in the laws, allowed the injury to take place and remain uncompensated for generations. ${ }^{, 208}$ The African American consciousness justifies society as the appropriate wrongdoer because "[s]ociety, unlike individuals, does not have a natural life," and "[t]he society that committed the wrong is still thriving."209

For reparation suits, the rights theory affects the ability to establish standing, as well as causation. Although past affirmative-action cases have not required plaintiffs to prove that they were the ones actually harmed by the wrongful act, ${ }^{210}$ the courts, in alignment with the dominant perspective, have shown an unwillingness to let anyone other than the actual wrongdoer

plaintiffs in a claim for reparations as "victim group members" and the defendants as "perpetrator descendants and current beneficiaries of [the] past injustice").

205 Verdun, supra note 7, at 619-20.

206 See id. at 620 ("Vicarious responsibility for the behavior of others only extends to individuals controlled by the persons assuming the responsibility.").

207 Id. at 625.

208 Id. at 637. In general, the norms and values of American society include an inherent racism that casts African Americans in an inferior light, which, in turn, provides inherent privilege to whites. See id. at 634 ("[S]ubconsciously, many decisions, heavily camouflaged in the cloak of meritocracy, are made based on ... beliefs [that African Americans are inferior to whites]."). Moreover, many people have "enjoyed an increased status and standard of living because of the national economic stability generated in part by the institution of slavery." Id. at 636 .

209 Id. at 637-38.

210 See, e.g., Fullilove v. Klutznick, 448 U.S. 448, 537 (1980) (Stevens, J., dissenting) (acknowledging that "[r]acial characteristics may serve to define a group of persons who have suffered a special wrong and who, therefore, are entitled to special reparations"); $c f$. Regents of Univ. of Cal. v. Bakke, 438 U.S. 265, 280 n.14 (1978) (finding that even if Bakke, a white medical school applicant, could not "prove that he would have been admitted in the absence of the special program, it would not follow that he lacked standing. The constitutional element of standing is plaintiff's demonstration of any injury to himself that is likely to be redressed by favorable decision of his claim"). 
assume or accept responsibility for compensation. ${ }^{211}$ Accordingly, the death of the last slave and slaveholder made reparations through judicial relief moot. ${ }^{212}$ One could imagine the courtroom argument: "To hold that descendants of the millions of blacks harmed throughout our history are entitled to compensation for the long-past injury of their ancestors"213 violates the principle that the parties compensated should be the parties harmed; ${ }^{214}$ likewise, to hold that the "current generations of whites should pay for the sins of earlier generations of whites" ${ }^{\$ 215}$ necessarily violates the principle that only those parties that caused the harm should compensate the plaintiffs. ${ }^{216}$ Thus, cases based in tort necessarily fail for lack of standing and/or causation. Therefore, the tort suit as a vehicle for African American reparations is not a viable option.

\section{B. Distributive Justice}

As happens with affirmative action, any legislative reparations scheme would at least indirectly impact the white American population. The tax dollars from all citizens fund the government, and government resourcessuch as land, employment, and education accommodations-must be shared. Outside the litigation context, however, "[g]roup responsibility and group entitlement are appropriate when the characteristic defining the group is of primary relevance to the reward or punishment in question, and when the group behavior can be said to be the product of voluntary effort by the individuals who comprise it."217 "Individuals who have not personally harmed minorities may nevertheless be prevented from reaping the benefits of the harm inflicted by the society at large."218

211 See, e.g., Wygant v. Jackson Bd. of Educ., 476 U.S. 267, 276 (1986) ("[A]s the basis for imposing discriminatory legal remedies that work against innocent people, societal discrimination is insufficient and over-expansive.").

212 See FISCUS, supra note 67, at 9-11 (discussing the two objections to the compensatory justice argument for affirmative action which are grounded in the compensatory principles).

${ }^{213}$ Id. at 10.

214 See id. at 9-11.

$215 \mathrm{Id}$. at 10.

216 See id. at 9-11; see also Miller, supra note 163, at 376 (discussing the requirement of the doctrine of continuing wrong that there be a continuing relationship between the wrongdoer and the plaintiff "to establish an on-going duty and breach of that duty").

217 FISCUS, supra note 67, at 9-11 (emphasis added).

218 Id. at 38 (arguing that the rights of whites are not violated by acting to restore the equilibrium that would have existed absent racist conditions); see also EDLEY, supra note 19, at 244-54 (discussing how most people would agree on the ideal result of eliminating racism, but that they disagree on the means of attaining that end, and describing how the rhetoric of arguing "rights" creates a trap that destroys all discussions). 
This is the nature of distributive justice. According to rights theorist Robert Nozick, "If the world were wholly just .... [t] he complete principle of distributive justice would say simply that a distribution is just if everyone is entitled to the holdings they possess under the distribution."219 The determination results from a three-step induction:

1. A person who acquires a holding in accordance with the principle of justice in acquisition is entitled to that holding.

2. A person who acquires a holding in accordance with the principle of justice in transfer, from someone else entitled to the holding, is entitled to the holding.

3. No one is entitled to a holding except by (repeated) applications of 1 and 2220

The relevance of this entitlement theory to reparations for African Americans is the inherent use of historical information, which extends the analysis to the intergenerational transfer of wealth and opportunity. Redistribution in the context of reparations does not mean a radical redistribution of wealth from the rich to the poor; rather, it is more a legitimate reallocation of that which has been unrightfully gained at the expense of African Americans. ${ }^{221}$ Under this analysis, the issue of unfair assignment of group responsibility is replaced by the notion of entitlement only to justly acquired holdings, and disgorgement of unjustly acquired holdings.

\section{American Precedent: The Civil Liberties Act}

\section{Japanese American Reparations}

Apart from the Freedmen's Bureau Acts, ${ }^{222}$ the key federal precedent for reparations ${ }^{223}$ as compensation for racially motivated government acts is

219 ROBERT NOZICK, ANARCHY, STATE, AND UTOPIA 151 (1974).

$220 \mathrm{Id}$.

221 FISCUS, supra note 67 , at 8-9, 37-50 (arguing that framing affirmative action in a distributive justice context helps negate the perception of unfairness to white males because individuals only receive what they would get in a fair world rather than individuals being compensated for past wrongs committed by past generations). In the context of African American reparations, the claim is for both.

222 See supra notes 42-53 and accompanying text (discussing the provisions of the Freedmen's Bureau Acts and the legislative troubles in overcoming President Johnson's vetoes).

223 Reparations have also been pursued on a state level. See FLA. STAT. ANN. $\$ 240.4126$ (West 1998) (creating a scholarship program for minority students enrolled at public universities, community colleges, and vocational-technical schools, with "preference given to the direct descendants of the Rosewood families"); 1921 Tulsa Race Riot Commission Act, OKLA. STAT. ANN. tit. 74, § 8201 (West Supp. 1998) (calling for the collection of interviews and evidence of the events in the Greenwood area of Tulsa on or about May 31 or 
the Civil Liberties Act (the "Act"), which provided restitution for the World War II internment of Japanese Americans and Aleuts. ${ }^{24}$

During World War II, all individuals of Japanese ancestry living in the United States were excluded from military zones and subject to forced evacuation and relocation to detention centers, without regard for their citizenship, pursuant to Executive Order $9066 .^{225}$ The Supreme Court upheld enforcement of the order. ${ }^{226}$

Four decades later, Congress established the Commission on Wartime Relocation and Internment of Civilians to study and document the impact of Executive Order 9066 on Japanese American citizens and permanent resident aliens. The Commission found that:

The excluded individuals of Japanese ancestry suffered enormous damages, both material and intangible, and there were incalculable losses in education and job training, all of which resulted in significant human suffering for which appropriate compensation has not been made.... [T] violations of the basic civil liberties and constitutional rights....

Along with an acknowledgment and apology for the "grave injustice ... done," 228 the Act provided for: (1) compensation in the amount of $\$ 20,000$ to individuals of Japanese ancestry who were interned, and living on the date of the enactment of the Act (or to their living heirs); and (2) a

June 1,1921 , in order to determine the need for reparations for racially motivated wrongful conduct); Rosewood Massacre Investigation \& Compensation Act, 1994 Fla. Sess. Law Serv. ch. 94-359 (West) (ordering compensation for any African American families of Rosewood demonstrating real or personal property loss damages up to $\$ 100,000$ for property, and allowing any African American who was present and affected by the 1923 riot and subsequent evacuation to be compensated for up to $\$ 150,000$ regardless of property loss); H.R. Con. Res. 22, 1st Ex. Sess., 1996 La. Sess. Law Serv. A-2 (West) (acknowledging and apologizing for Louisiana's role in the institution of slavery); cf. S. 318, 177th Leg. (Mass. 1992) (calling for reparations for slavery, the slave trade, and invidious discrimination); African-American Reparation Study Commission Act, H.R. 934, 179th Leg. (Pa. 1995) (calling for the acknowledgment of slavery in Pennsylvania, and establishing a commission to study the de jure and de facto discrimination against freed slaves and their descendants, and to recommend the appropriate remedy, including reparations).

${ }^{224}$ See 50 U.S.C. app. § 1989-1989d (1994). The current proposed legislation for African American reparations is closely modeled after the precursor to the Civil Liberties Act that called for a study of the internment impact. See H.R. 40, 105th Cong. (1997) (calling for the establishment of "a commission to examine the institution of siavery, subsequent de jure and de facto racial and economic discrimination against African Americans ... and to make recommendations to the Congress on appropriate remedies").

${ }^{225}$ See Exec. Order No. 9066, 7 Fed. Reg. 1407 (1942) (authorizing the establishment of military areas and the exclusion therefrom of any or all persons, citizens, or aliens).

226 See Korematsu v. United States, 323 U.S. 214, 216 (1944) (sustaining a conviction for violation of the exclusion order, under the auspices of "[p]ressing public necessity").

22750 U.S.C. app. $\$ 1989 \mathrm{a}(\mathrm{a})$.

228 Id. 
public education fund to facilitate public awareness of the internment and prevent a recurrence. ${ }^{229}$ The entitlement to compensation now extends to all children of excluded individuals eligible under the Act who were deprived of liberty by exclusion from their families' domiciles. ${ }^{230}$

\section{Reparations to the Aleuts}

According to the statement of Congress:

[T] he Aleut civilian residents of the Pribilof Islands and the Aleutian Islands west of Unimak Island were relocated to temporary camps in isolated regions of southeast Alaska where they remained, under United States control and in the care of the United States, until long after any potential danger to their home villages had passed. ${ }^{231}$

The grant to Aleuts is often overlooked when the Act is discussed in relation to reparations for African Americans. ${ }^{232}$ The Commission's findings with respect to the Aleuts, however, are instructive in establishing governmental liability for misfeasance:

The United States failed to provide reasonable care for the Aleuts, and this resulted in widespread illness, disease, and death among the residents of the camps; and the United States further failed to protect Aleut personal and community property while such property was in its possession or under its control.

The Act granted compensation to Aleut residents for property taken or destroyed by the United States during World War II and "for injustices and unreasonable hardships endured" while the Aleuts were under United States control during the war. ${ }^{234}$

\section{An Analogy to African Americans}

The monetary reparations paid to Japanese Americans were funded by the tax dollars of United States citizens. Obviously, the broad group that shouldered responsibility for payment of the compensation included at least "four groups of "innocents": "1) people who were not born in 1941;

229 Id. $\$ 1989$.

${ }^{230}$ See Ishida v. United States, 59 F.3d 1224 (Fed. Cir. 1995); see also Watanabe v. United States, 66 F.3d 345 (Fed. Cir. 1995) (granting compensation under Ishida); Sato v. United States, 33 Fed. Cl. 818 (1995) (same).

231 50 U.S.C. app. $\$ 1989 \mathrm{a}(\mathrm{b})$.

232 See Magee, supra note 169, at 904-06 (discussing reparations to Japanese Americans but excluding discussion of the Aleuts); Verdun, supra note 7, at 646-59 (same).

23350 U.S.C. app. § $1989 \mathrm{a}(\mathrm{b})$.

234 Id. $\S 1989(5)$. 
2) people who were alive but objected strenuously to the internment; 3) people who immigrated to the United States after the internment was over; and 4) a host of other people who just had nothing whatsoever to do with it." 235 One way in which the African American case is more complex than that of the Japanese Americans and Aleuts is that African Americans have suffered from not one, but many harmful acts by both private citizens and state and federal governments. Ironically, the existence of private actors should make the argument for legislative reparations stronger in the case of African Americans, because it clouds the innocence of the so-called "innocents." If tax dollars were used to fund reparations to African Americans, the group responsible for payment would include the parallel "innocent" groups to the Japanese American reparations scenario: "1) people who were born after slavery ended ...;2) abolitionists; 3) people who immigrated after slavery ended; and 4) people who are not descendants of slaveholders."236 The difference between the African American and the Japanese American scenario is that most, if not all, of the "innocents" in the African American case have benefited from many of the wrongs giving rise to the reparations. $^{237}$

In sum, the Civil Liberties Act recognized tangible and intangible harms caused by federal action and inaction. The Act established a precedent for legislative compensation to a particular racial group that suffered unique injuries due to racially motivated law enforcement. Based on a comparison of the "victim" experiences, it is difficult to fathom a reasonable justification for not enacting the African American Reparations bill. Simple substitutions in the language of the congressional findings for the Japanese Americans and the Aleuts could easily provide a starting point to summarize the case for African Americans:

The [enslaved] individuals of [African] ancestry [and their descendants] suffered enormous damages, both material and intangible, and there were incalculable losses in education and job training, all of which resulted in significant human suffering for which appropriate compensation has not been made.... [T] hese [were] fundamental violations of the basic civil liberties and constitutional rights.... ${ }^{238}$

The United States failed to provide reasonable care for the [Africans and their descendants], and this resulted in widespread illness, disease, and death among

${ }^{235}$ Verdun, supra note 7 , at 653.

236 Id. at 654.

237 "[W]hite Americans are not guilty of practicing slavery and most are not actively engaged in economic discrimination, but most are collectively the beneficiaries of slavery and economic discrimination." Id. at 636 (citation and internal quotations omitted).

23850 U.S.C. app. $\$ 1989 \mathrm{a}$ (a); see supra text accompanying note 227. 
the [African American population]; ${ }^{239}$ and the United States further failed to protect [African Americans and their] personal and community property [by uniform enforcement of the law].

\section{B. Reconciling African American Reparations and the Equal Protection Clause 241}

In the wake of Adarand Contractors, Inc. v. Peña, ${ }^{242}$ race-based congressional legislation must now withstand the same strict scrutiny standard that has been applied to the states since City of Richmond $v$. J.A. Croson Co., ${ }^{243}$ and that standard applies whether or not the measure benefits or burdens the affected race.

In his extensive analysis of Reconstruction Era legislation, Eric Schnapper argues that the legislative intent behind the Fourteenth Amendment confirms the constitutionality of certain race-based remedies. ${ }^{244}$ Schnapper bases his argument on the contemporaneous consideration of the

239 For example, post-slavery incidents like the Tuskeegee syphillis experiments "ha[ve] contributed greatly to distrust among African Americans of the medical establishment." See Donna Franklin, Beyond the Tuskegee Apology, WASH. PoST, May 29, 1997, at A23 (discussing the mistrust that African Americans have for the health care facilities as a result of racially motivated medical abuse).

In 1939, seven years after the Tuskegee experiment began, the Birth Control Federation of America (the successor to the American Birth Control League) planned a "Negro Project" directed at the "mass of Negroes, particularly in the South," because it considered that segment of the population "least fit, and least able to rear children properly."

Id. The Department of Health Education and Welfare "estimated that in 1972 between 100,000 and 200,000 sterilizations had been funded by the federal government." Id. "[T]his distrust [resulting from historic medical abuse] in turn has life-or-death consequences for [African Americans] who are disproportionately affected by HIV, AIDS and other illnesses-and who may not seek treatment for fear of being misused." Id.

240 50 U.S.C. app. \$ 1989a(b); see supra text accompanying note 233.

241 By inverse incorporation, the 14th Amendment extends to federal action via the Fifth Amendment. See Bolling v. Sharp, 347 U.S. 497, 499 (1954) (noting that although the Fifth Amendment does not have an equal protection clause, sometimes "discrimination may be so unjustifiable as to be violative of due process").

242515 U.S. 200, 227 (1995) (holding that federal programs using racial classifications must meet the strict scrutiny standard announced in City of Richmond v. J.A. Croson Co., 488 U.S. 469 (1989)).

243488 U.S. 469,494 (1989) (holding that the strict scrutiny standard applies equally to measures both benefiting and burdening minorities).

244 See Schnapper, supra note 31, at 754 (arguing that "the legislative history of the fourteenth amendment is not only relevant to but dispositive of the legal dispute regarding constitutional standards applicable to race-conscious affirmative action plans"). 
Fourteenth Amendment and the Freedmen's Bureau Acts. ${ }^{245}$ He argues that:

The framers of the fourteenth amendment cannot have intended it to nullify remedial legislation of the sort Congress simultaneously adopted.... [The legislative debates] provide clear examples of the kinds of reasons and circumstances that would justify the use of race-conscious remedies in the eyes of [the framers]. Conversely, the arguments made unsuccessfully against those programs by the legislators who also opposed the fourteenth amendment cannot represent the standards embodied in the amendment. ${ }^{246}$

Schnapper's analysis has not been $100 \%$ persuasive before federal courts in refuting the argument that race-preferential remedies violate the Fourteenth Amendment per se by discriminating against those not targeted by the remedy. ${ }^{247}$ His argument, however, is particularly relevant to the reparations issue, when the objectives and ideologies behind the Reconstruction Acts and Amendments are understood.

Congress specifically enacted the Freedmen's Bureau Acts and the Civil Rights Act of 1866 to ensure the citizenship rights of African Americans. Thus, "[t] here is no violation of equal protection when society acts to restore the equilibrium that would have naturally occurred under nonracist conditions. Indeed, to fail to maintain the equilibrium by using final-stage measures of merit is to allow the processes of racism to culminate in their inevitable inequities."248 Foner notes that the major Reconstruction legislation resulted from a "complex series of legislative compromises and maneuvers" sponsored by senators and congressmen with significant influence. ${ }^{249}$ According to Schnapper's discussion of the legislative history, two dominant motivations drove supporters of the Freedmen's Acts. The first was that the Acts would aid the freedmen's transition from slavery to freedom, and thus alleviate the social burden associated with the four million Afri-

245 See id. at 768,784 (noting the concurrent debates, the common sponsors of the $\mathrm{Bu}-$ reau Acts and the 14th Amendment, and the view that the Bureau Act secured protection for the freed slaves).

246 Id. at 789.

247 See Coalition for Econ. Equity v. Wilson, 122 F.3d 692, 693 (9th Cir. 1997) (challenging, but failing to stop, the enactment of Article $1, \S 31$ of the California Constitution (Proposition 209) on the grounds that it denied equal protection and conflicted with federal civil rights statutes); see also CAL. CONST. art. 1, \&31 ("The state shall not discriminate against, or grant preferential treatment to, any individual or group on the basis of race, sex, color, ethnicity, or national origin in the operation of public employment, public education, or public contracting."); Hopwood v. Texas, 78 F. 3d 932, 932 (5th Cir. 1996) (holding that the use of race as a factor in law school admissions in favor of increasing minority enrollment violates the 14th Amendment).

248 FiSCUS, supra note 67, at 38-39.

249

FONER, supra note 7, at 130. 
cans who were uneducated and without land or assets. ${ }^{250}$ The second was to give the freed slaves the opportunity to establish their economic independence. ${ }^{251}$

Thaddeus Stevens, Speaker of the House, argued for redistribution of the land to enable the emergence of a "new class of black and white yeomen," who would replace the planter class of the south, serve as the basis for future southern political and social power, and ally themselves with the northern Republican middle class. ${ }^{252}$ Stevens was a proponent of enabling the economic independence of freedmen, so as to prepare them for full citizenry which would eventually include voting rights. ${ }^{253}$ The sponsors of the Fourteenth Amendment were Congressman Stevens, Senator Wade, and Congressman Bingham, who authored the Amendment. The sponsors of the Bureau Act were Senator Trumbull and Congressman Eliot. ${ }^{254}$ The proponents of the Bureau Acts and the Fourteenth Amendment subscribed to the promotion of self-sufficiency, so as to preclude an indefinite dependence on public assistance. ${ }^{255}$ They supported special assistance for freedmen in view of the freedmen's lack of "political influence of whites to advance their own interests" 256 and for the "safety of the nation." 257

Given that the motivation behind reparations to African Americans is to provide the means to enfranchise a group that has been intentionally denied the social status, resources, and well-being required to enjoy the civil and political rights to which every United States citizen is entitled, legislative reparations follow the precedents for allowing race-based remedies.

${ }^{250}$ See Schnapper, supra note 31, at 755-56 (discussing the responsibilities of the newly created Bureau of Freedmen's Affairs that were designed to further this goal).

251 See id. at 758 ("After a life of servitude ... these freedmen ... have this right ... to earn among us their own subsistence." (quoting CONG. GLOBE, 38th Cong., 1st Sess. 572 (1863) (statement of Rep. Thomas Eliot))).

252 FONER, supra note 7, at 134.

253 See id. at 133 (discussing Stevens's view that unless Congress delayed giving suffrage to freedmen until they were free from the "economic coercion" of the southern states, the south would not be transformed).

${ }^{254}$ See Schnapper, supra note 31, at 784 (noting that all voted in favor of both the Amendment and the Acts).

${ }^{255}$ See id. at 758 (discussing Congressman Eliot's proposition that taxing whites to aid African Americans at that time would help African Americans to become self-sufficient).

256 Id. at 768 (summarizing Congressman Phelps's argument). nelly)).

Id. (quoting CONG. GLOBE, 39th Cong., 1st Sess. 590 (1866) (statement of Rep. Don- 


\section{ANTICIPATING THE OBSTACLES TO IMPLEMENTATION}

The African-American Reparations Commissions Act is closely patterned after the precursor to the Civil Liberties Act. ${ }^{258}$ The purposes of H.R. 40 are: (1) to acknowledge the fundamental injustice, cruelty, brutality, and inhumanity of slavery in the United States and the thirteen American colonies between 1619 and 1865; and (2) to establish a commission to examine the institution of slavery, subsequent de jure and de facto racial and economic discrimination against African Americans, and the impact of these forces on living African Americans, and to make recommendations to the Congress for appropriate remedies. ${ }^{259}$

Representative Conyers, author of H.R. 40, has not yet specified what form of reparations should be pursued in the event of a positive finding by the commission. ${ }^{260}$ The question of implementation for an African American reparations scheme, however, is not only what should the compensation be, but who are the appropriate beneficiaries. As previously stated, it is beyond the scope of this Comment to exhaustively state the types and extent of harms suffered by African Americans as a result of slavery and ensuing private and government discriminatory action. Accordingly, it is not this author's intention to assume the formidable task of definitively stating what reparations for African Americans should be. Rather, this is an attempt to address some of the problems that have been or may be posed as obstacles to the implementation of reparations for African Americans.

\section{A. Who?}

Unlike the injured group in the case for Japanese American reparations, ${ }^{261}$ the African Americans injured from slavery and the ensuing systemic discrimination number in the millions. ${ }^{262}$ Considering the pool of

258 See Commission on Wartime Relocation and Interment of Civilians Act, Pub. L. No. 96-317, 94 Stat. 964 (1980) (codified at 50 U.S.C. app. § 1981 (1988)).

${ }^{259}$ See African American Reparations Commission Act, H.R. 40, 105th Cong. (1997).

260 An official specification at this point could cloud Representative Conyers's objectivity in calling for a commission regarding H.R. 40. See Betsy Peoples, A Simple Gesture, EMERGE, Sept. 1997, at 42, 42-46 (reporting on an interview with Representative John Conyers and others, including an attorney for the National Coalition of Blacks for Reparations).

261 See Verdun, supra note 7, at 655 (noting that the injured group of Japanese Americans-those actually interned-is "relatively small, and members of the class are identifiable from existing records").

262 The black American population as of 1996 was reported as 33,503,000. See U.S. DEP'T OF COMMERCE, STATISTICAL ABSTRACT OF THE UNITED STATES 18 tbl.18 (1997). Note that this number may include people of various ethnicities, such as Hispanics, that one would not normally identify as African American. See id. at 19 tbl.19 n.1. 
black Americans, it is safe to concede that not all black people in America are descendants of African slaves. ${ }^{263}$ Moreover, individuals who are descendants of slaves may not necessarily have descended from African American slaves. Despite these uncertainties, there are several possible approaches to answering the "who" question to identify the appropriate beneficiaries of African American reparations.

One approach is to adjust the degree of eligibility according to the number of generations an individual's family has resided in America. Such an approach could reasonably limit entitlements and avoid overburdening those who are not African American. ${ }^{264}$ Eligibility based on generational considerations would also be consistent with the argument that black/white inequities are partially due to the intergenerational transfer of wealth among white Americans.

The distinction of origin and generational citizenship, however, loses some of its significance in some relation to the length of time an African American family has been in America. An immigrant of African descent will suffer the same discrimination and advantages as indigenous African Americans regardless of his actual citizenship. In time, the cumulative harm to that immigrant's generation residing in America will approach the harm caused to indigenous African Americans. Furthermore, by reason of the slave experience in the Caribbean, England, South America, and other regions whence blacks have migrated to this country, the entitlement to remediation might be considered absolute. Thus, an alternative approach is to require only that beneficiaries have American citizenship.

Ultimately, the appropriate beneficiary of a remedial measure will depend upon the particular remediation. The difficulty in identifying beneficiaries-and which beneficiaries have suffered which particular injuries-can be alleviated by applying the fluid recovery mechanism sometimes used in class action suits. ${ }^{265}$ "In a fluid recovery the money is either distributed through a market system in the way of reduced charges or is used to fund a

263 See id. at 11 tbl.8 (showing the data for immigrants from areas including the Caribbean, South America, and Africa).

264 Note that even children of Japanese American origin who were born after their families were excluded from the original family home are now entitled to compensation under Ishida. See supra text accompanying note 230 (discussing recent case law that grants compensation to children for exclusion from their family's domicile); see also Ishida v. United States, 59 F.3d 1224 (Fed. Cir. 1995).

${ }^{265}$ Fluid recovery is used in class actions suits where the number of injured individuals is excessive, and the individuals are unlikely to prove their claims individually or cannot be given notice. See, e.g., Simer v. Rios, 661 F.2d 655, 675 (7th Cir. 1981) (noting that fluid recovery is appropriate where injured individuals are not likely to come forward because of their large numbers). 
project which will likely benefit the members of the class. ${ }^{.266}$ The use of this mechanism would be appropriate, because legislative reparations-as this Comment justifies them-would embody policies of disgorgement, compensation, and deterrence. ${ }^{267}$ The population of African American citizens should be treated as the class of injured parties, and divided into subclasses as necessary to determine eligibility for specific remedies.

\section{B. What and How?}

If the overall goal of reparations for African Americans is to eventually enable a harmonious and diverse democracy, then the remedies and compensation must necessarily target areas critical to social well-being and economic empowerment. That, in turn, should ensure the opportunity to enjoy civil rights and enable political empowerment.

\section{Non-Specific Reparations}

A logical starting point for African American reparations is to extend an acknowledgment and apology for the grave injustices done, and at least provide: (1) some amount of monetary compensation for individuals (or their living heirs) who were either slaves or alive during the Jim Crow era, and living on the date of the enactment of the Reparations Act; and (2) a public education fund to facilitate public awareness of slavery, the Jim Crow era, and systemic discrimination, and to prevent their recurrence. ${ }^{268}$ Although no amount of money can compensate for the injuries suffered, governments have issued some form of monetary compensation to many groups whose fundamental human rights have been violated. ${ }^{269}$ Yet, even assuming an arbitrary sum set at an amount of only $\$ 20,000$ per individual, some would argue that the total monetary award to African American beneficiaries would approach unfeasible and excessive sums.

${ }^{266}$ Id. (footnotes omitted); see also RICHARD L. MARCUS \& EDWARD F. SHERMAN, COMPLEX LITIGATION: CASES AND MATERIALS ON ADVANCED CIVIL PROCEDURE 47 (2d ed. Supp. 1997) (criticizing the market system of fluid recovery for consumer plaintiffs in the form of coupons because that practice fails to give real relief to the plaintiff class).

${ }^{267}$ See Simer, 661 F.2d at 676 ("The general inquiry is whether the use of [fluid recovery] is consistent with the policy or policies reflected by the statute violated. This matter can be more particularized into an assessment of to what extent the statute embodies policies of deterrence, disgorgement, and compensation.").

${ }^{268}$ This mirrors the Civil Liberties Act. See 50 U.S.C. app. $\$ 1989$ (1994); supra text accompanying notes $238-40$ (describing how minimal revision of the Civil Liberties Act could encompass the harms that African Americans have suffered).

${ }^{269}$ See supra notes 182-83 (noting the monetary reparations from Germany to Jewish Holocaust victims and from Japan to Korean comfort women). 
An alternative to issuing actual monetary awards is to allow a comparable tax exemption over a period of years. This approach essentially results in the African American beneficiaries paying themselves, because the result is theoretically the same as if the beneficiaries' tax dollars were pooled and then redistributed. Arguably, such an exemption for African Americans increases the tax burden on nonreparee taxpayers, particularly if the tax burden of nonreparees is increased specifically to cover what would otherwise be contributed absent the exemption. Even with an increased tax obligation, nonreparee taxpayers might consider the exemption a substantial subsidization because reparees would still be entitled to all the benefits enjoyed by the average citizen. Nevertheless, this potential subsidization should not be a barrier to monetary compensation because such compensation has been afforded to Japanese Americans and Aleuts. ${ }^{270}$

A "public education fund to increase awareness" is a non-specific remedy that would provide redress for the gross historical understatement of the African American contribution to the development of the United States. Instead of reserving one month out of the year to acknowledge the various histories of non-white, non-male American groups, ${ }^{271}$ the education curriculum must move away from its current monocultural, Eurocentric focus, toward a more inclusive reflection of American culture and history. African Americans as a group, as well as American society as a whole, would eventually benefit as fallacies of inferiority and social irresponsibility are replaced by a true understanding of how integral the African American presence has been to the success of our capitalist foundation.

\section{Specific Reparations}

It is simply unrealistic to think that relief from the effects of deeprooted inequities and discrimination can be resolved by a lump sum payment. Therefore, reparations must include specific remedies that address the specific harms suffered. Areas for reparation measures include housing and land ownership, education, employment, and loans.

To the extent that non-specific and specific remedies can be accommodated by affirmative action, reparations and affirmative action must not be mutually exclusive. We should, however, revisit the construct of affirmative action and resolve the misconceptions that hinder the effectiveness of

270 See supra text accompanying notes 235-37 (discussing how the existence of private actors in wrongdoings against African Americans strengthens the argument for tax dollar subsidization as reparations in this case). Month."

For example, February is "Black History Month" and March is "Women's History 
these programs. One drawback that makes affirmative action susceptible to attack is that there are no clear goals that indicate progress and mark the point at which affirmative action is no longer necessary. In the context of reparations, the goals are to ensure full citizenship and to correct past wrongs, where the measure of success is a tangible metric.

\section{a. Housing Discrimination Remedies}

A brief analysis of the two remedies currently used for systemic housing discrimination in federally subsidized housing programs-"mobility relief" and "equalization relief,272 - provides a useful illustration of how specific remedies should be used. "Mobility relief attempts to alleviate the isolation caused by segregation by moving victims of discrimination closer to better schools and a better supply of jobs in safer areas."273 This is accomplished via one of two methods. Either the victim is transferred to a unit or project within a development in which the victim's race does not predominate, or the victim receives Section Eight certificates to enable "federally assisted housing in nonracially impacted areas."274 In contrast, equalization relief includes such remedies as "housing rehabilitation and modernization, the submission of [detailed] equalization plans ..., housing code enforcement, provision of certain amenities and tenant services, demolition of dilapidated housing with one-for-one unit replacement, and real community redevelopment addressing neighborhood conditions, municipal services, and exposure to environmental hazards.,275 Equalization relief has generally been more difficult to obtain than mobility relief. $^{276}$ From the perspective of a reparations advocate, equalization is a better remedy because it remedies the discrimination in a way that empowers the victim.

Most often, victims of housing discrimination live in racially segregated areas. These areas become undesirable not because of the purely social as-

272 See generally Adams, supra note 131 (discussing the two mobility programs and equalization relief). In addition to its use to remedy discrimination in public-housing site selection and tenant selection, assignment, and transfer, mobility relief has been awarded to plaintiffs challenging school segregation. See id. at 448-49.

273 Id. at 447.

274 Id. Use of Section Eight certificates in "(non)racially impacted areas" is one remedy to discrimination in public-housing site selection because it enables certificate holders to live outside of race-concentrated urban areas. See id. at 447 \& n.159.

275 Id. at 464 (footnotes omitted).

276 See id. at 466 (describing the difficulties encountered in seeking equalization relief because of the intense research required to prove that "the discriminatory actors maintained superior government-subsidized housing for whites" and the narrowed scope of antidiscrimination laws). 
pect of segregation, ${ }^{277}$ but because of the consequential impact of discrimination on services, job availability, and safety in the areas. ${ }^{278}$ Equalization accommodates the right to choose by allowing the affected individuals to remain in an area that would be desirable, but for the effects of discrimination. When municipal services, school facilities, crime deterrence, and protection from environmental hazard exposure are brought on a par with nonsegregated areas, the civil and social aspects of full citizenship are restored. Equalization relief also enables political empowerment by allowing African Americans to remain in a concentrated area. This is significant for strengthening the political voice-dilution of political strength occurs when mobility is the sole relief option. ${ }^{279}$

\section{b. Education Remedies}

Another drawback of affirmative action is that the term is simultaneously used to describe programs that are (1) vehicles to correct past discrimination; (2) vehicles to diversify (based on gender, race and class); as well as (3) vehicles to give candidates who lack the traditional qualifications the opportunity to prove themselves. ${ }^{280}$ The implications of the latter two stigmatize the first because whites (particularly, males) feel excluded or "discriminated against" when all three initiatives are thought to be one and the same. ${ }^{281}$ In the context of reparations, uncertainties and ambiguities can

${ }^{277}$ For instance, one study reports that, given the choice, African American mobility relief recipients preferred to relocate to areas with significant African American populations. See id. at 452.

${ }^{278}$ See id. at 464-66 (noting the pervasive influence of discrimination on community infrastructure).

279 Vote dilution occurs when the African American population in a district is decreased, such that the collective group vote-assuming the group tends to vote the same way-is outweighed by the majority white vote. See Fuentes-Rohwer, supra note 153, at 210 (discussing this and other diminutive vote practices); see also supra note 78 (discussing proposed alternative voting schemes that might enhance minority representation). Attempts to draw voting district lines that maximize the number of majority African American districts are subject to strict scrutiny. See Shaw v. Reno, 509 U.S. 630, 644, 647 (holding that allegations that North Carolina's redistricting legislation amounted to racial gerrymandering-concentrating a dispersed minority population in a single district by disregarding traditional districting principles-supported a claim for relief under the 14th Amendment).

The concept [of affirmative action] subsumes a set of programs ranging from, at its mildest, wide advertising of positions to prompt more people to apply or extensive recruitment of potential applicants, through the use of ranges and goals in hiring, to, ultimately, at its most severe, the use of fixed quotas for hiring and promotion.

FISCUS, supra note 67 , at ix-x.

${ }^{281}$ See id. at X ("[M]any opponents of affirmative action label all disliked programs 'quotas' because of the negative resonance of that term ...."). 
be eliminated because the initiative is to compensate for harm suffered. The measure of progress is equalization.

As applied to education, this may call for short-term remediation, in which affirmative action is taken to level the playing field for the next three school-aged generations. A hypothetical scenario might be as follows: Phase one: For the next three generations (or at least for the next thirty-six years), any pre-college educational institution that is heavily populated by African American students from historically disadvantaged areas, for the express purpose of providing remedial education, could be governmentfunded and/or receive government contracts. Such schools would be geared toward college preparatory programs at the high school level. Phase two: Then, for the following two generations (or at least over the following twenty-four years), implement proactive recruiting and financial assistance for minority applicants that meet the "standard" entrance criteria to public and private colleges. Simultaneously, create college access programs for disadvantaged students who show academic potential but do not meet the current standard entrance criteria due to prior discrimination in education. The objective of such a scenario would be to level the playing field in preparation for the removal of race and ethnicity indications from all college application materials starting twelve years after the end of Phase two; and removal of the same from all pre-college applications starting at end of Phase one, thus achieving a race-neutral meritocracy in education.

\section{c. Other Remedies}

Discrimination in areas such as loans and employment are more difficult to address, because these involve more subjective evaluations on the part of private individuals. To the extent that fair loan qualification can be monitored, reparations could grant lower loan rates for a specific period of time to African Americans who have suffered discrimination as compensation for the loss in equity and economic opportunity. Where such subjective evaluations are involved, however, non-specific reparations-such as the above-mentioned "public education fund to increase awareness" - can only attempt to sway individual attitudes.

\section{CONCLUSION}

In sum, I have argued that providing reparations for African Americans is not only a justifiable remedy, but a prerequisite to racial harmony and any movement toward race neutrality. I have shown-though by no means is the illustration exhaustive-that current inequalities between African Americans and white Americans are rooted in historic patterns of discrimi- 
nation by federal, state, and private actors. Reparations for African Americans must come in the form of legislation, because the courts provide no available recourse, given the procedural barriers of sovereign immunity, statutes of limitations, causation, and standing. In addition to general relief that would benefit this multicultural nation as a whole, specific remedies and compensation can be targeted to rectify specific inequities. Thus, legislative reparations to African Americans would not be unlike previous racebased remedies that were deemed constitutional.

There is an old saying that applies here: Sweep around your own front door before you sweep around mine. It is time for America to ensure the citizenry rights of African Americans with the same commitment and zeal that America has demonstrated in protecting human rights abroad. 
* $* * * * * * *$ 